\title{
Political Stability and Fiscal Policy \\ Time Series Evidence for the Swiss Federal Level since 1849
}

\author{
LARS P. FELD \\ CHRISTOPH A. SCHALTEGGER
}

CESIFO WORKING PAPER NO. 2691

CATEGORY 1: Public FinANCE

JUNE 2009
An electronic version of the paper may be downloaded
- from the SSRN website:
- from the RePEc website:
- from the CESifo website:
www.SSRN.com
www.RePEc.org
www.CESifo-group.org/wp




\title{
Political Stability and Fiscal Policy Time Series Evidence for the Swiss Federal Level since 1849
}

\begin{abstract}
This paper explores the role of political stability on fiscal policy choices in a time-series analysis over 158 years on the Swiss federal level. We argue that the fiscal-commons problem of public finances is affected by the time-horizon of a finance minister. Arguably, the incentives for an incumbent to maintain a good reputation with sound policy decisions are stronger the longer the time-horizon of a respective term. In addition, a finance minister who succeeds to stay a long time in office normally enjoys a politically powerful position towards the parliament, the administration and the interest groups to influence policy decisions. In contrast, frequent government turnover weakens the position of the finance minister.
\end{abstract}

JEL Code: H11, H50, H61, D78.

Keywords: political stability, fiscal policy, constitutional changes.

\author{
Lars $P$. Feld \\ University of Heidelberg \\ Alfred-Weber-Institute \\ Bergheimerstrasse 58 \\ 69115 Heidelberg \\ Germany \\ lars.feld@awi.uni-heidelberg.de
}

\author{
Christoph A. Schaltegger \\ economiesuisse \\ Hegibachstrasse 47 \\ 8032 Zürich \\ Switzerland \\ christoph.schaltegger@economiesuisse.ch
}

We would like to thank Urs Altermatt, Thushyanthan Baskaran, Charles B. Blankart, Reiner Eichenberger, Heinz Hauser, Gebhard Kirchgässner, Marcel Savioz, the participants of the Wartensee Conference celebrating Gebhard Kirchgässner's 60th Birthday, April 18-19, 2008 at Schloss Wartensee (Switzerland) and of the Annual Meeting of the European Public Choice Society, April 2-5, 2009 in Athens (Greece). 


\section{Introduction}

In 1918, Schumpeter (1918, [1953], p. 5) contended that people's nature, its cultural achievements, social structure, and what their countries' policies offer could be read from its fiscal history. ${ }^{1}$ Fiscal policy appeared to him as the best expression of world history. Since this publication, public choice analysis and political economics have followed his suggestions, though more often unconsciously than deliberately, to investigate how constitutional frameworks, institutional environments and political events influence fiscal policy in different countries. For example, Peacock and Wiseman (1961) studied the impact of wars (and other deep crises) on government growth and argued for the existence of a displacement effect. While tax resistance before a crisis prevents politicians from extending the state's grip on the economy, a crisis reduces this resistance because taxpayers accept the necessity to raise government resources to overcome a critical situation. After the crisis, taxpayers have gotten accustomed to the increased tax burden and the government is not compelled to reduce its activities to the level prevailing before the outbreak of the crisis. Similar to wars, the Great Depression served such a purpose and allowed for the extension of social welfare states in many Western societies (see Wallis 2000 for the U.S.). In the U.S., this even led to a revision in the basic structures of American federalism (Wallis 1991).

The political economy of government size (Tridimas and Winer 2005) attributes the factors shaping fiscal policy to the demand and supply side. Thus, Peacock and Wiseman's (1961) displacement effect results from an extraordinary demand for government expenditure during a crisis. Lott and Kenny's (1999) analysis underlines the importance of changes in the demand for income redistribution and is thus in line with the Meltzer-Richard (1981) model. Similarly, the classical studies by Wagner (1892) and Brecht (1932) emphasize income and urbanization, respectively, as determinants of the demand for government activity. Concerning the supply side, the relative productivity of public services as a reason for the "cost disease" (Baumol 1967), the inherent desire of Leviathan governments to exploit citizens (Brennan and Buchanan 1980), and partisan influences (Hibbs 1977, Blais, Blake and Dion 1993) provide grounds for a relative increase in government activity.

However, as Tridimas and Winer (2005) or Besley and Case (2003) emphasize, these approaches somewhat ignore the impact of constitutional and institutional structures on fiscal policy

1. The original quote goes back to the German sociologist Rudolf Goldscheid who argued that "The budget is the skeleton of the state stripped of all misleading ideologies". 
outcomes. ${ }^{2}$ Only recently have the constitutional differences between majoritarian and proportional representation systems or between presidential and parliamentarian systems (Persson and Tabellini 2000, 2003, Milesi-Ferretti, Perotti and Rostagno 2002), but also those between direct and representative democracies (Feld and Kirchgässner 2001a, Feld and Matsusaka 2003, Matsusaka 1995, 2004) been studied in comparative political economics. The starting point is the fiscal commons problem that arises when political decision-makers in the legislature or the executive provide benefits from public projects concentrated on particular groups of society while the costs of these projects are spread across the whole population through general taxation. This particular common pool problem has been known at least since the seminal work by Buchanan and Tullock (1962, chapters 10 and 11), but it could occur in different forms. While the U.S. discussion mainly pays attention to the effects of pork-barrel politics in legislatures on public spending (Weingast, Shepsle and Johnson 1981, Inman and Fitts 1990, Gilligan and Matsusaka 1995, 2002), the European discussion focuses on coalition or cabinet size of the executives as characteristics of a fiscal commons problem determining spending, budget deficits and public debt (Roubini and Sachs 1989a, 1989b, Kontopoulos and Perotti 1999, Volkerink and de Haan 2001, Perotti and Kontopoulos 2002). This distinct emphasis may be interpreted as a hint to the importance of the constitutional differences between majoritarian/presidential and proportional representation/parliamentarian systems.

Comparing direct and representative democracies, Feld and Kirchgässner (2001a, 2001b), Feld and Matsusaka (2003), Feld, Schaltegger and Schnellenbach (2008) and Schaltegger and Feld (2009) argue (and present evidence for Switzerland) that the fiscal commons problem is less severe under direct democracy due to difficulties to organize log-rolling in referenda and initiatives. Their results of a lower level of public spending and of less centralized spending and revenue in direct democracies, which they obtain for a panel of the Swiss cantons between 1980 and 1998, are supported by Funk and Gathmann (2007) in a larger panel of Swiss cantons between 1890 and 2000. These studies focus on fiscal policy of the Swiss cantons and how it is affected by fiscal referenda. Fiscal policy at the Swiss federal level is however seldom analyzed. Only the works by Gebhard Kirchgässner stand out. For example, Kirchgässner and Prohl (2008) provide a time series analysis of federal fiscal policy in Switzerland from 1900 to 2002. Their main concern is the sustainability of federal fiscal policy. There is also an earlier time series analysis by Kirchgässner and Pommerehne (1997) for all three go-

2. Tridimas and Winer (2005) underline the additional importance of political influence without discussing however constitutional or institutional structures either. 
vernment levels in Switzerland and for Germany from 1961 to 1987. They include political variables in addition to characteristics of demand and supply for government activity and socio-demographic controls. However, they do not look at institutional factors such as proportional representation or direct democracy and the time period they study is too short to investigate short-run and long-run effects in a differentiated way. ${ }^{3}$

This paper contributes to the political economy of fiscal policy using time series data for the Swiss federal level. In contrast to previous analyses, the data set extends from the creation of the Swiss constitution in 1849 until 2007. It thus covers the full time period with many historical events that need to be captured in addition to economic and socio-demographic factors. Moreover, the long time series allows us to investigate potential short-run and long-run relations between the economic and fiscal variables. Our main research interest, however, consists in testing the hypothesis whether political stability induces sound fiscal policies in the longrun. Political stability is mainly captured by the time horizon of the finance minister, but is evaluated against the background of exogenous shocks like the two world wars or the Great Depression and constitutional changes like the switch to proportional electoral representation.

The remainder of the paper is organized as follows: In section 2, the impact of political stability on fiscal policy outcomes and how it is achieved under different constitutional regimes are discussed. The empirical strategy follows in section 3. The results will be discussed in section 4 while section 5 offers some concluding remarks.

\section{Long-term political stability and fiscal policy: Some theoretical considerations}

Starting from Buchanan's and Tullock’s (1962) perspective of the fiscal commons problem, fiscal policy results from a differential success of societal groups which reap particular benefits from public policy, but spread its costs broadly over the whole population through general taxes. The core element of the fiscal commons problem is the notion of targeted spending and general taxes. As the marginal costs of each spending project are lower than the marginal benefits for the individuals in groups which are particularly privileged, these groups demand higher than socially optimal spending. Government activity is consequently extended beyond its optimal scope. It should, however, be noticed that this exploitation of those not participating

3. See also Kirchgässner and Pommerehne (1988) for a detailed analysis of fiscal developments in Switzerland. There is an earlier study by Meier et al. (1973), which uses time series of revenue, spending and federal grants from 1950 - 1969 for all three government levels, but their focus is on income, inflation and population size. In addition to the recent panel studies on cantonal fiscal policy, there are of course several earlier papers like the one by Hauser et al. (1975) using cantonal cross section data, or the ones by Pommerehne and Frey (1976), Pommerehne (1978) and Pommerehne and Schneider (1978) using local data. 
in log-rolling arrangements, which bestow a privileged access to the fiscal commons, is generally restricted by a membership externality which stems from the intersection of members among separate majority coalitions (Buchanan and Yoon 2004).

The fiscal commons problem is affected by different constitutional systems. The argument is that majoritarian electoral systems strengthen the accountability of representatives in contrast to proportional electoral systems, where the link between the electorate and the representative is much looser. In majoritarian systems, each representative in the legislature thus aims at ensuring re-election in his constituency by providing benefits from federal spending projects to his district. Only a part of the legislature will be successful in bringing home such funds. The successful incumbents exchange votes according to a log-rolling arrangement resulting in pork-barrel politics (Weingast, Shepsle and Johnsen 1981). Such log-rolling arrangements are particularly successful in presidential regimes as legislators are less disciplined by partisan considerations. In parliamentary democracies, parties gain more importance as the government depends on a confidence vote of the different fractions in parliament. The argument is one of weak checks and balances. Parties must ensure their majority and ascertain a stronger independence from pork-barreling. In a parliamentary system with proportional representation, the fiscal commons problem occurs more directly and explicitly in the executive. Due to proportional representation, a parliament with more than two parties becomes highly probable, such that coalitions between parties must often be built to form a government. Log-rolling is then explicitly achieved in a coalition contract (Roubini and Sachs 1989a, 1989b). Similar considerations obtain when different wings of a large party gain ministerial representation in government (Perotti and Kontopoulos 2002).

In sum the traditional fiscal commons problem occurs with respect to public spending and subsequently public revenue. In more recent times, the role a fiscal commons problem plays in explaining the increasing indebtedness in OECD countries is additionally emphasized (von Hagen and Harden 1995, Velasco 1999, 2000, Volkerink and de Haan 2001). The same mechanism could be described with the further complication of spreading the costs of concentrated spending projects not only to the current, but also to future taxpayers. The exploitation of the fiscal commons then implies excessive debt.

Several solutions to fiscal commons problems are discussed in the literature. Most prominently formal fiscal rules restrain overspending and excessive debts. ${ }^{4}$ Moreover, budgetary proce-

4. See Poterba (1997) or Kirchgässner (2002) for surveys on the effects of fiscal institutions on fiscal policy, Feld and Kirchgässner (2008) for evidence on the cantonal debt brakes, and Schaltegger (2002) for both. 
dures may constrain public debt (von Hagen 1992, Hallerberg and von Hagen 1999, Hallerberg, Strauch and von Hagen 2007). In these analyses, the role of an agenda setter in the budgetary process, e.g. the finance minister, is emphasized. By coordinating the proposals of the different spending ministers, such a central player is able to reduce the fiscal commons problem if budgetary goals are tight and strictly enforced. From that perspective the fiscal commons problem is a particular kind of government weakness which finds its expression in different forms of fragmentation from large coalitions and cabinets to pork-barrel spending and divided government (Alt and Lowry 1994, Alesina and Rosenthal 1996). ${ }^{5}$ Fiscal policy under such a severe threat of common pool problems lacks the intertemporal reliability which is important for private actors in taking their economic dispositions. An institutionally strong finance minister thus helps to establish political reliability and stability. Institutional strength of the finance minister could be established by different measures, for example a right to veto the budget law, as in Germany, or the right to set pre-specified spending targets.

In addition to institutional strength, government stability, i.e. when a finance minister succeeds in remaining in office for longer time horizons, can reduce the fiscal commons problem. Arguably, the incentives for an incumbent to maintain a good reputation with sound policy decisions are stronger the longer the time-horizon. In addition, a finance minister who succeeds in staying a long time in office usually enjoys a politically powerful position towards the parliament, the administration and the interest groups. In contrast, frequent government turnover weakens the position of the finance minister. A long time-horizon on the job vests such a person with a natural advantage with respect to spending ministers who have a lower tenure. Moreover, as Besley and Case (1995) argue, a longer time horizon provides the incentives to build reputation in office. The reputation gained as a finance minister may boost her prospects for becoming prime minister or head of state or, after finishing the term, pursuing a career in the private sector. Career concerns could thus provide for beneficial incentives. This also holds if the reputation accumulated in office promotes someone's career in the private sector. While Besley and Case (1995) underline the detrimental effects of term limits when career concerns play a role, De Haan and Sturm (1994) emphasize the importance of the frequency with which government changes for the growth in public debt. In any case, factual

5. Using a large panel data set of Norwegian local governments, Borge (2005) emphasizes the role of political strength for the common pool problem caused by competing interest groups. Measures of political strength are obtained by looking at party fragmentation of the local council, the type of political leadership and ideological differences within the political leadership. 
government stability is arguably important for sound fiscal policies. We thus have a closer look on government stability in an institutionally strong polity, namely in Switzerland.

\section{Empirical strategy}

In order to investigate the impact of political stability on fiscal policy, we conduct a time series analysis for the Swiss federal level over a long time horizon between 1849, i.e. one year after the foundation of the Swiss Confederation, to 2007 which is the year in which the Swiss debt brake is supposed to work without qualifications. Our data set thus covers the whole time period for which Switzerland has existed as a Confederation. Choosing the Swiss federal level for such an investigation is natural as the political system slowly evolved without being deranged by major constitutional eruptions or revolutions, but still exhibits several important constitutional and political changes. More importantly, the federal government consists of a coalition between the same four parties since 1959. In this respect, Switzerland is the country with the highest degree of political stability in Europe.

In one of the previously conducted time series analyses for Switzerland from 1961 to 1987, Kirchgässner and Pommerehne (1997) study Swiss (and German) fiscal policy by starting from an Almost Ideal Demand System (AIDS) as their econometric approach. This notwithstanding they are forced to estimate reduced form models owing to the prevailing simultaneity between public spending, revenue and budget surplus. The simultaneity in fiscal policy decisions prevents them from imposing meaningful exclusion restrictions such that the structural form of the model cannot be identified. In another time series analysis for the Swiss federal level from 1900 to 2002, Kirchgässner and Prohl (2008) conduct unit root, stationarity and cointegration tests as well as tests on structural breaks to investigate the sustainability of fiscal policy. While the structural break they find for the Second World War underlines the influence of particular exogenous events on fiscal policy, the authors are subsequently only interested in the sustainability question. According to their results, Swiss fiscal policy has been (weakly) sustainable for the whole time period and for the sub-period since $1946 .{ }^{6}$

As we are more interested in the effect of political and constitutional factors on fiscal policy than on sustainability of fiscal policy, we propose the following reduced form model:

$X_{t}=\beta_{0}+\beta_{1}$ CTRL $_{t-1}+\beta_{2}$ Political Stability $_{t-1}+\beta_{3}$ Constitutional Changes $_{t}+$ Trend $+\varepsilon_{t}$,

6. Similarly, Afonso and Rault (2008) investigate fiscal sustainability in the EU using stationarity and cointegration analysis. They conclude that overall, fiscal policy in the EU15 has been sustainable during the period 1970 to 2007. However, the general result does not hold in any individual case. 
where $t$ are the year indices. $X$ represents the budget variables, i.e. budget surplus, public debt, public spending or revenue, each normalized by GDP. In addition to the time trend which is included in each regression, the vector of economic controls (CTRL), lagged by one period, consists of the oil price, real GDP, nominal interest rates and population size. Unfortunately, data on other structural variables, like age of population, the share of urban population or the unemployment rate are not available or are not consistently measured over this long time period. Real GDP is included to capture potential income effects of the demand for public goods. Population size controls for the extent of publicness of government spending due to non-rivalness in consumption and is thus included. The oil price is supposed to proxy supply shocks. Nominal interest rates are included to capture business cycle effects.

With respect to public spending and revenue, we expect GDP to exert a positive influence following Wagner's (1896) arguments. Population size is supposed to have a negative influence on spending per capita if Samuelson's (1954) theory on public goods holds true. A simple politico-economic argument, however, suggests the opposite sign. A larger population size implies a broader tax base such that a Leviathan government could raise revenue. If the Peacock and Wiseman (1961) mechanism prevails, i.e. if the ability to extend public spending depends on revenue restrictions, higher spending might result from a larger population. The sign of this variable is thus theoretically indeterminate. Interest rates reflect the business cycle, and might be negatively associated with budget surpluses and positively with public debt.

In addition to these economic variables, the model contains dummy variables capturing particular events in Swiss history which could be hypothesized to have affected fiscal policy. One dummy variable takes on the value of 1 , and zero otherwise, for the years of the two world wars between 1914/18 and 1939/45 and the German-French-War in 1870/71. Another dummy variable takes on the value of one for the time of the Great Depression between 1929 and 1933. Furthermore, the years with major tax amnesties on the federal level in 1940, 1945 and 1969, years for which a federal income tax was levied (1916, 1917, 1921, 1924, 1925, 1928, 1929, 1932, 1940-2007) and the drastic devaluation of the Swiss franc in 1936 are controlled for. Moreover, dummy variables which mark the shift from a majoritarian to a proportional representation system in 1919, the creation of the Swiss National Bank (SNB) in 1907 and of the federal old age pension system (AHV) in 1948 are included in the model.

With respect to these variables, and following the analysis by Peacock and Wiseman (1961), we could hypothesize an unambiguously positive effect of the two world wars on public expenditure and revenue as well as on debt, but a negative effect on the budgetary surplus. In 
addition, we expect the introduction of the AHV to increase public spending, revenue and debt. It indicates the new era of the welfare state in Switzerland and thus exemplifies the demand for income redistribution as suggested by Meltzer and Richard (1981). Also, following Persson and Tabellini (2000), the switch from a majoritarian system to proportional representation supposedly increases spending, deficits and debt.

While additional instruments of direct democracy were introduced at the federal level since the foundation of the Swiss Confederation, direct democracy is controlled for by the number of referenda and initiatives, lagged by one period as well as a one period lag of voter turnout. According to the partisan theory, ideological dispositions are often supposed to affect fiscal policy as well (Hibbs 1977, Blais, Blake and Dion 1993). In particular, left-wing parties are assumed to favor a larger public sector and incur higher indebtedness. In our econometric model, ideology is captured for the executive by including a dummy variable adopting the value of one if a Social Democratic finance minister was in office and zero otherwise. In addition, the influence of the SPS is measured by the share of its seats in the national parliament. Both variables are lagged by one period. Although the Social Democrats are usually hypothesized to favor a larger public sector, it should also be noted that the rise of the Social Democratic Party marks a boost of political competition at the federal level. In the beginning of the Confederation, federal politics was dominated by the (then largely protestant) Free Democratic Party (FDP). Its main political competitor, the (then largely catholic) Christian Democratic Party (CVP) entered the federal government in the end of the $19^{\text {th }}$ century in 1891 . But both parties represented groups of the population which were more or less conservative. They could be expected to both favor conservative fiscal policies, but thus also to target spending to their clienteles. The rise of social democrats, in particular before the Second World War, threatened the rents of the CVP and the FDP obtained from the public budget. As long as the SPS was not included in the federal government (until 1943), the political competition which was triggered by its rise could have led to a reduction in rents and possibly also spending. As a part of the governing coalition, it could be expected that the additional party in government increased spending because of the fiscal commons problem.

Political stability, as the final variable included in the analysis, has a particular meaning in this paper. It is measured by the time horizon of the finance minister. The measure is constructed retrospectively adopting a value of one in the first year of a finance minister and then counting continuously to the end of his term. Following the combined arguments by Besley and Case (1995) and the fiscal commons literature, a longer time in office provides a finance 
minister with incentives to perform well due to career concerns. The longer he is in office, the more experience will help him to enforce budgetary goals against the different spending ministers. Arguably, the incentives for an incumbent to maintain a good reputation with sound policy decisions are stronger the longer the time horizon of a respective term. In addition, a finance minister who succeeds in staying a long time in office normally enjoys a politically powerful position towards the parliament, the administration and the lobbies to influence policy decisions. In contrast, frequent government turnover weakens the position of the finance minister. We thus expect this variable to exert a positive effect on budget surpluses and a negative effect on public debt as well as on spending and revenue.

Political stability in this context does not mean the lack of exogenous shocks or the lack of coups and revolutions. With respect to the former, important exogenous shocks like the wars or the Great Depression could of course be observed in the time period covered by our data set. Regarding the latter, no coup or revolution took place in Switzerland. Since 1959, Switzerland experiences even an extraordinary degree of political stability in the sense that the government consists of the same four coalition partners. This system also allows a finance minister to stay in office without being much threatened by elections. He has a relatively high degree of discretion as to whether he wants to stay, to become minister in another ministry or to retire. Infrequently, Swiss finance ministers are forced to step down by their party or by political (and legal) scandals. The perspective adopted here is thus on the personality of the finance minister. It is a particular form of political leadership we are interested in.

The test strategy followed in this paper is straightforward. First, the time series characteristics of the data set are investigated by conducting unit root and cointegration tests. Tests on structural breaks are not conducted as they are well documented in the paper by Kirchgässner and Prohl (2008) for the Second World War. Moreover, several less important breaks are covered by different dummy variables in the reduced form regressions. Depending on the unit root and cointegration tests, the final models for the four dependent budgetary variables are specified. In any case, given the structural break induced by the Second World War, these analyses are conducted for the whole sample and the two sub-samples before and after the war excluding these war years. For the two sub-samples, some exogenous variables may be meaningless, e.g. if a particular event did not occur in the sub-period, and are then excluded. 


\section{Results}

\section{Anecdotal evidence}

A first look at Swiss federal fiscal policy since 1849 already reveals interesting patterns. From the foundation of the constitution until the first integral revision of the constitution in 1874, the federal level carried a relatively light fiscal burden. The government was mainly concerned with the formation of a federal army and the construction of a federal infrastructure to promote mobility and education. The source of income consisted of customs and excise duties. Usually, the federal budget was balanced in the first 30 years with the exception of extraordinarily high spending during the German-French-War in 1870/71. From 1874 to 1914 the federal government gained new competencies from the cantons in the sense of Popitz' Law (1927). For example, the nationalization of formerly private railway companies to the Schweizerische Bundesbahnen SBB, the formation of a central bank (the SNB), laws to subsidize education and farmers, the construction of alpine roads and some inchoate social security transfer programs. Since the upgrading of government tasks at the federal level was not followed by new tax sources, the federal government warned the parliament repeatedly against the introduction of new spending proposals - with mixed success. Until the eve of the First World War, the federal government nevertheless conducted a relatively sound fiscal policy (Weber, 1969). Neither do budget surpluses (in percent of GDP) exhibit important turns into the negative (Figure 1), nor does public debt (in percent of GDP) reveal any boost or much volatility (Figure 2). In the second half of the $19^{\text {th }}$ century, the Swiss Confederation appears to be a different one from today. However, it should be noted that a slightly increasing trend in the debt ratio could already be observed. Similarly, federal expenditure (Figure 3) and revenue (Figure 4), both in percent of GDP, indicate similar increasing trends in public sector activity. Admittedly, the level of relative public sector size on the federal level was still well below $10 \%$.

During World War I, government finances ran into huge deficits. This was the result of extraordinarily high military spending as well as falling government revenue due to drastically decreasing customs duties. Though the government introduced a federal income and wealth tax in 1915, additional revenue was not raised until 1916/17 and was small in amount. Thus, Switzerland was defraying the financial burden of World War I with debt (government bonds) and the seignorage from the Swiss National Bank SNB. After World War I, government spending was not immediately cut back to the initial level and the creation of new taxes was vetoed by public referenda. Thus, public finances recovered only slowly. In autumn 1929, federal government finances were hit anew by the onset of the Great Depression. The government 
answered with the implementation of a "deflation-policy”. This policy resulted in severe economic and social turbulences which culminated in 1936, when the government had to devaluate the national currency Swiss Franc by 30\% (Weber, 1969). All in all, the First World War led to a remarkable change inducing a first noticeable federal budget deficit of 4\% of GDP in 1915 and leading to stronger shifts in spending and revenue although Switzerland was not actively involved in the war. These unexpected deficits of the war period led to an increase in federal debt to $31 \%$ in 1922, before larger surpluses reversed that development during the years 1924 to 1937 (including the great depression).

In 1938, a "sales-tax" was introduced on the federal level due to financial needs of the upcoming World War II. In contrast to World War I, the government wanted to be prepared this time. However, the federal council was only partially successful. The reintroduction of a federal income tax, changes in stamp duties and the introduction of a balanced-budget-rule were vetoed in parliament. Despite all the preparations by the government, the financial burden of World War II went far beyond the scope of World War I. In 1940, the government made use of its extended constitutional powers and introduced several new taxes together with a tax amnesty. 29\% of all extraordinary military spending were covered by the additional revenues (Weber, 1969). During the Second World War, again the budget deficits, spending and revenue increased tremendously which led to big increases in federal debt. In 1941, the federal budget deficit amounted to 13\% of GDP. Federal spending rose from 5.5\% in 1937 to $18.6 \%$ in 1944 . Federal debt consequently rose from $27.4 \%$ in 1937 to $63.2 \%$ in 1944.

The period after the war brought a time of fiscal consolidation at the federal level. From 1946 to 1970 , only in the three years 1951, 1952 and 1967 could small budget deficits of 0.13 to $0.88 \%$ of GDP be observed. Federal debt was reduced to $7 \%$ of GDP in 1969 . However, the growth in federal spending and revenue continued after the war. Like Peacock and Wiseman (1961) argued, federal spending and revenue did not come back to the same relative size of the years before the war and subsequently rose at an accelerated pace, notwithstanding small ups and downs triggered by economic activity. 
Figure 1: Budget Surplus in \%of GDP, Swiss Federal Level, 1849-2007

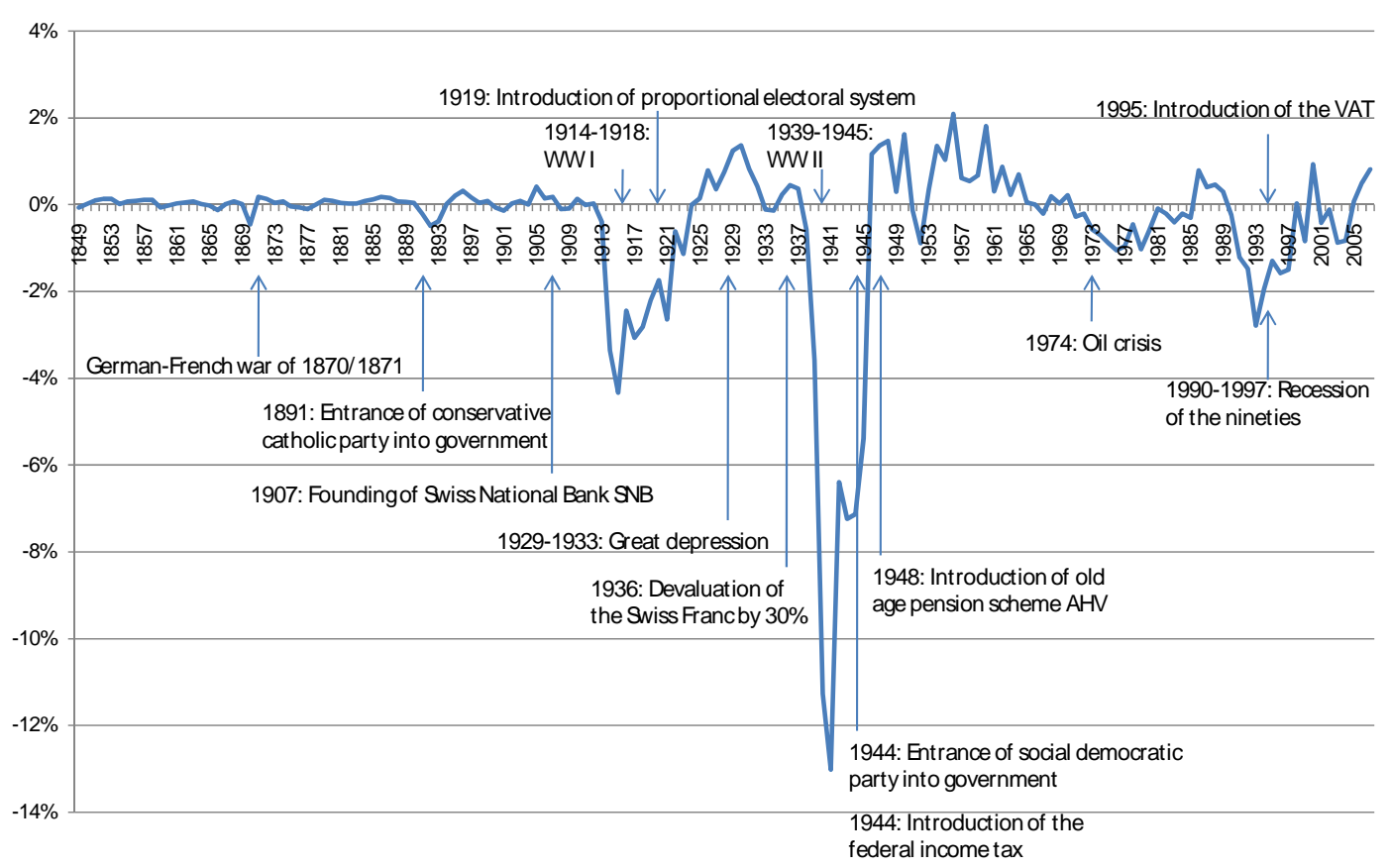

Figure 2: Public Debt in \%of GDP, Swiss Federal Level, 1849-2007

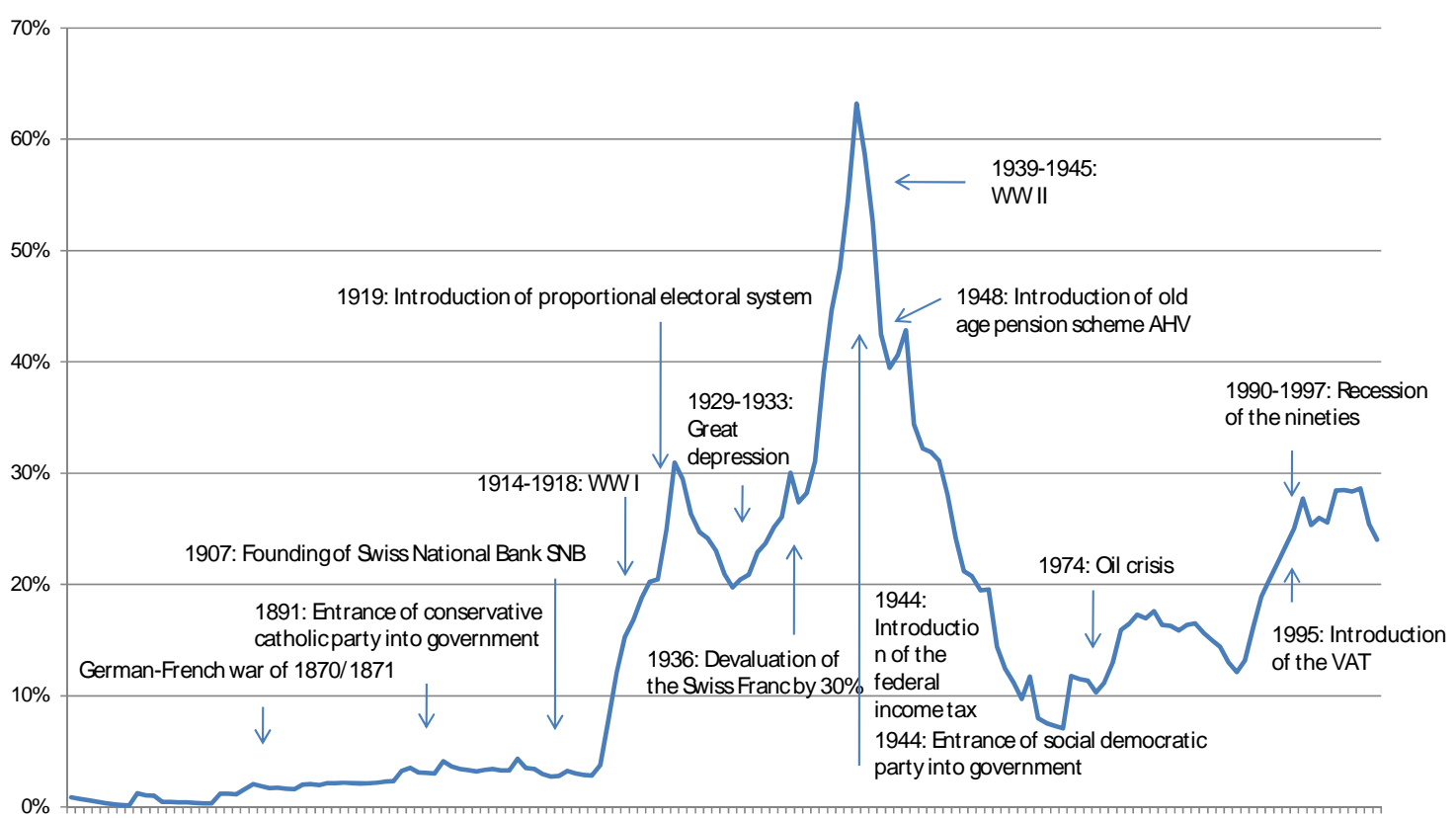

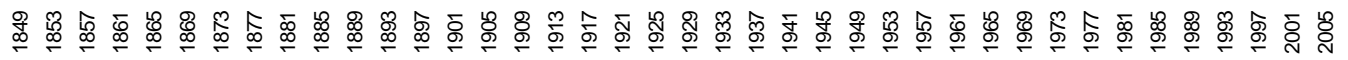


Figure 3: Public Spending in \%of GDP, Swiss Federal Level, 1849-2007

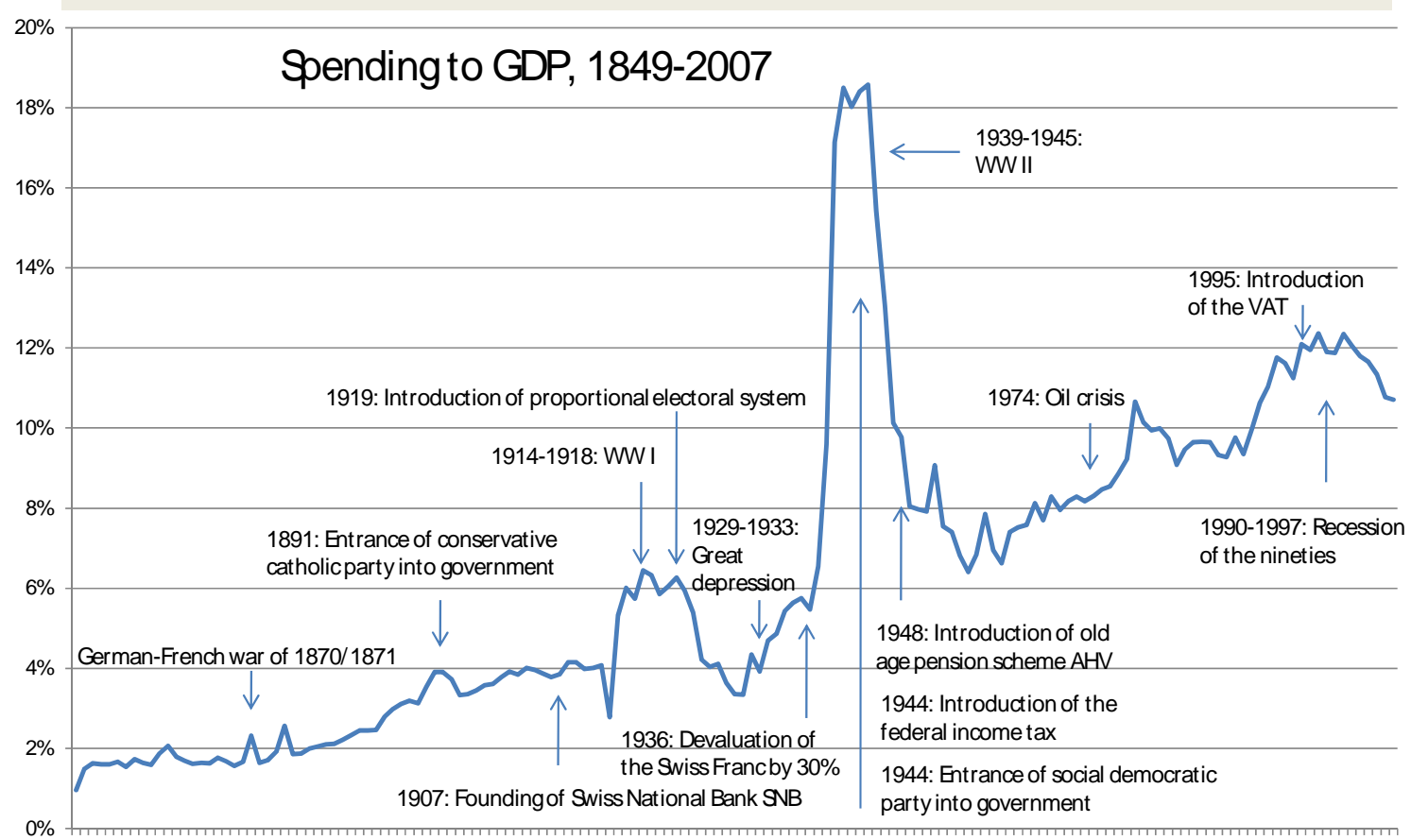

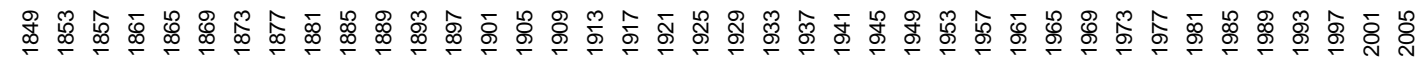

Figure 4: Public Revenue in \% of GDP, Swiss Federal Level, 1849-2007

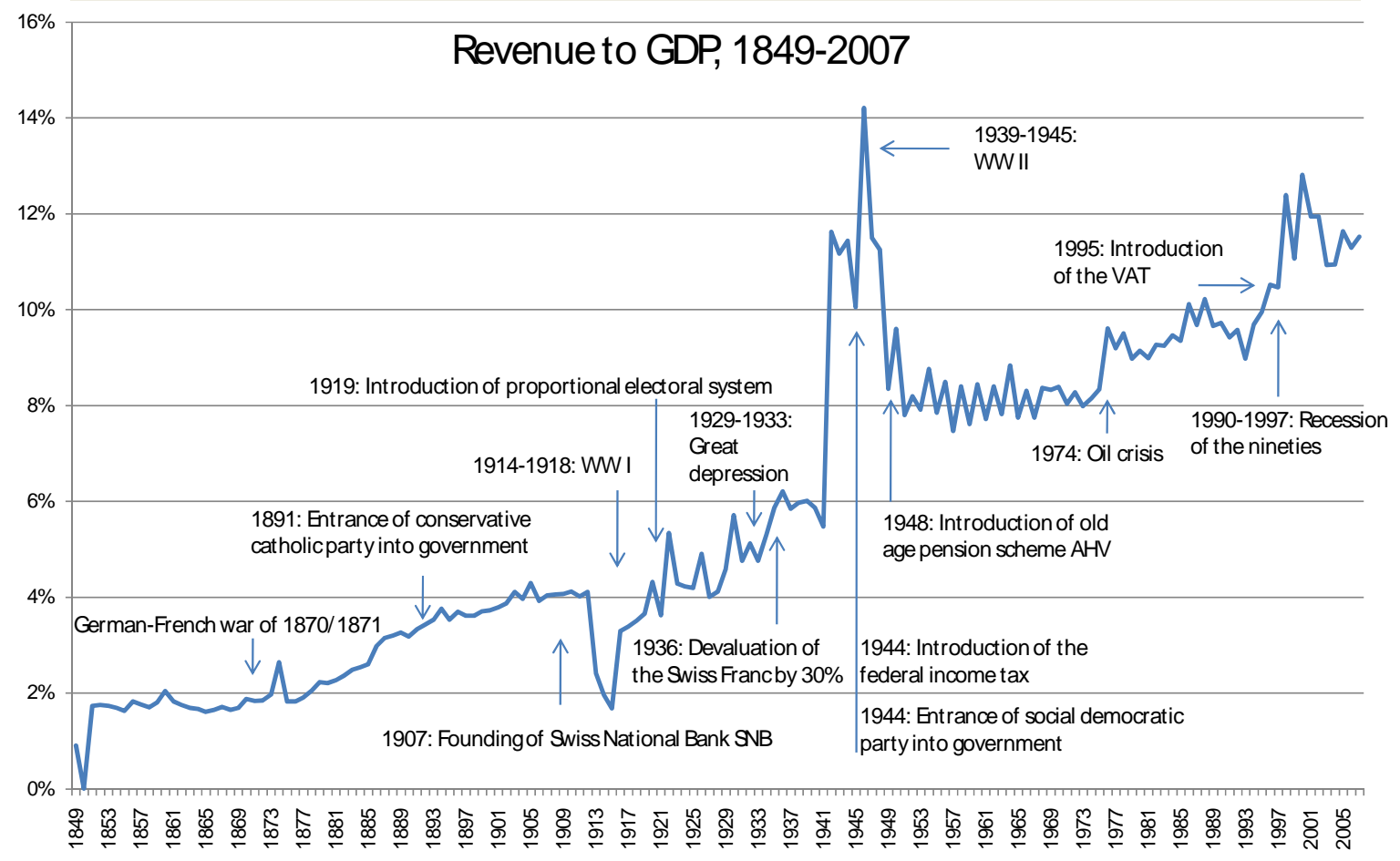


Figure 5: Average Federal Budget Surplus, in \% of GDP, for Swiss Fnance Ministers, 1849-2007

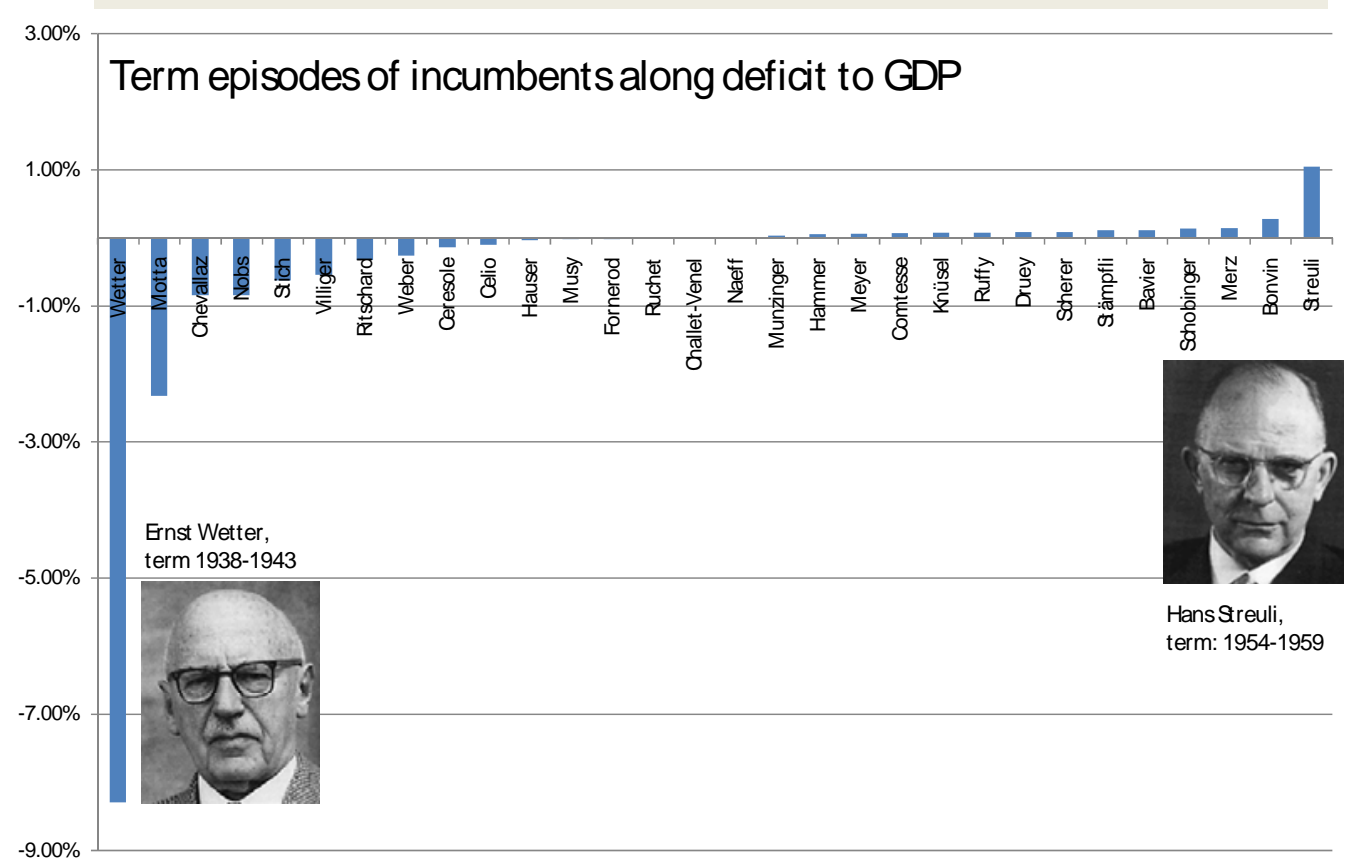

The development of government finances after 1960 was characterized by two trends: a first wave of government expansion was accompanied by good economic conditions so that public finances could be held more or less balanced even during the oil crises. The second wave of government expansion occurred during the 1990s and was accompanied by an economic downswing and relatively high rates of unemployment which ended at the beginning of the $21^{\text {st }}$ century. Additionally, in 1995 the VAT was introduced at the federal level which expanded the revenue capacity of the federal government considerably compared to the former sales tax. In 2001 voters agreed in a referendum to a balanced-budget-rule aimed to fight continued deficit spending (Frey, 2007).

Regarding the performance of each individual minister of finance, Figure 5, Figure 6 and Appendix $C$ illustrate their relative success with respect to federal budget surpluses and federal spending. It certainly is a bad coincidence that Giuseppe Motta and Ernst Wetter served as federal finance ministers during the First and Second World War, respectively. Unsurprisingly, their performance appears to be the worst in terms of average budget deficits and spending growth. Motta, who served from 1912 to 1919 as minister of finance, increased federal spending by $1.8 \%$ on average per year and presented budget deficits of $2.32 \%$ on average. Federal debt thus increased during his time in office by 17.43 percentage points. In his term between 
1938 and 1943, Wetter had to bear federal deficits of 8.3\% of GDP on average per year. Federal debt rose by 23.54 percentage points during this time.

Jean-Marie Musy served from 1919 to 1934 and thus the longest time as federal finance minister. Overall, his performance with respect to fiscal policy is relatively good. ${ }^{7}$ He stressed the importance of a balanced budget and the stability of the Swiss franc. He reduced federal spending in percent of GDP by 1.18 percentage points, on average presented an almost balanced budget of $-0.02 \%$ and moderately increased federal debt (in percent of GDP) by 3.27 percentage points. The first social democratic finance minister was Ernst Nobs between 1944 and 1951 who could also offer a good performance favored by the postwar consolidation mood. He reduced public debt in percent of GDP by 28.83 percentage points overall.

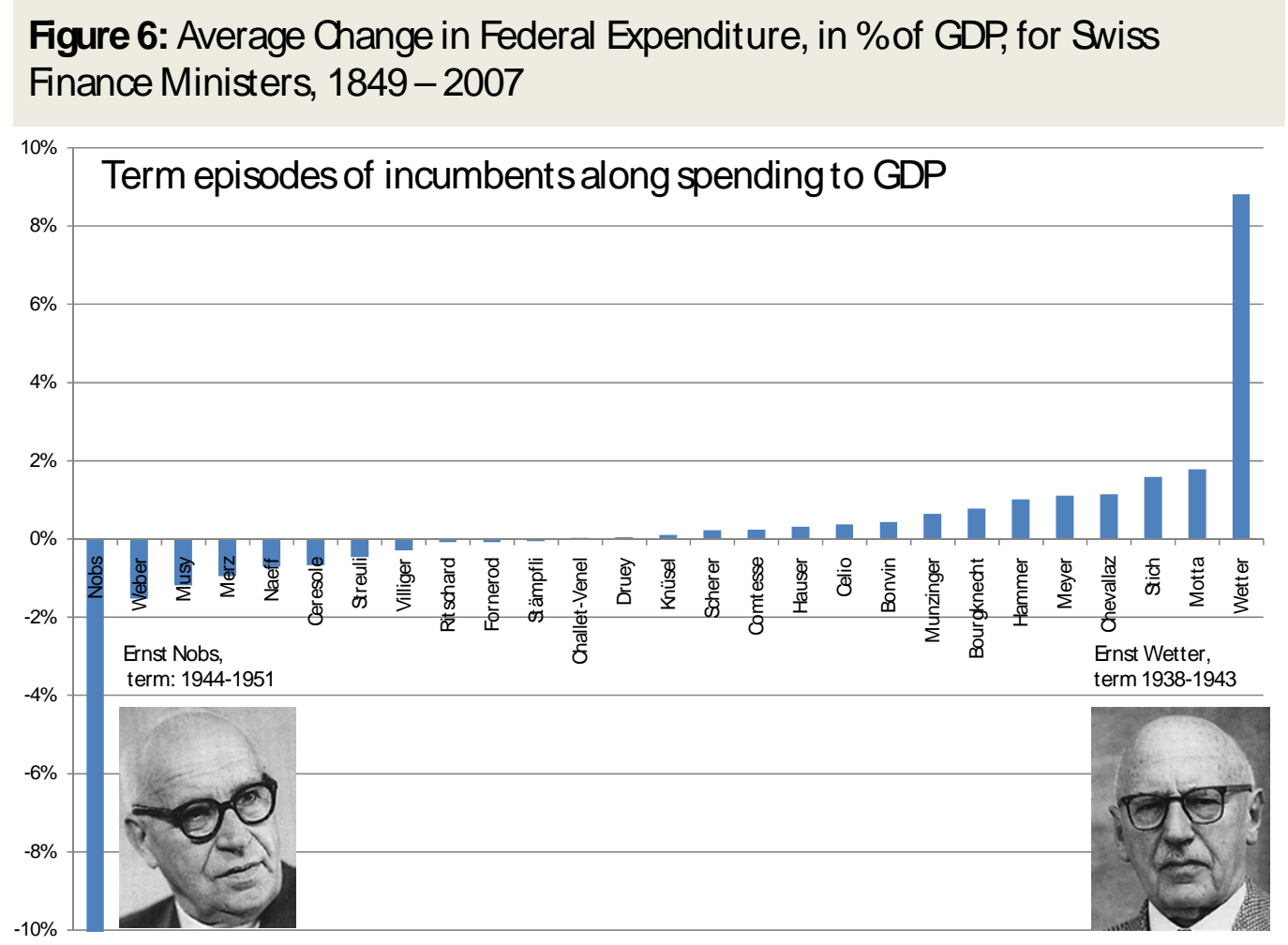

\section{Results from Unit Root Tests and Cointegration Tests}

Of course the anecdotal evidence can only illustrate the development of Swiss federal fiscal policy and the performance of the finance minister. A more rigorous analysis must be conducted to test the hypothesis on political stability and sound public finances. A first step towards

7. More debated is his role during World War II: Musy was close to fascist ideas and had connections to important persons of the NSDAP. However, as a private person without political or diplomatic status, he helped to rescue 1200 Jews from the KZ Theresienstadt into Switzerland. 
a serious analysis consists in the elaboration of the time series characteristics of the main fiscal policy variables (Kirchgässner and Wolters 2007). First, tests for unit roots are presented in order to test on the stationarity of fiscal policy at the federal level. We conduct Augmented Dickey-Fuller (ADF) tests and Philipps-Perron (PP) tests, but abstained from also presenting the KPSS tests. The ADF and PP tests for the whole sample are much in line with the results of Kirchgässner and Prohl (2008) such that the KPSS test results would not have provided further insights in order to proceed in our analysis.

Table 1 Test for Unit Roots, Swiss Federal Level, 1849 - 2007

\begin{tabular}{|c|c|c|c|c|c|c|}
\hline \multirow[t]{2}{*}{ Variables } & \multicolumn{3}{|c|}{ ADF test } & \multicolumn{3}{|c|}{ Philipps-Perron (PP) test } \\
\hline & Level & $\begin{array}{l}\text { Level } \\
\text { with } \\
\text { Trend }\end{array}$ & $\begin{array}{l}\text { First } \\
\text { Differences }\end{array}$ & Level & $\begin{array}{l}\text { Level } \\
\text { with } \\
\text { Trend }\end{array}$ & $\begin{array}{l}\text { First } \\
\text { Differences }\end{array}$ \\
\hline \multicolumn{7}{|c|}{$1849-2007$} \\
\hline Budget Surplus (in \% of GDP) & $-4.036^{* *}$ & $-5.610 * *$ & $-11.423^{* *}$ & $-4.425 * *$ & $-4.419 * *$ & $-11.377 * *$ \\
\hline Public Debt (in \% of GDP) & -1.185 & -2.438 & $-7.631 * *$ & -1.597 & -1.854 & $-7.555 * *$ \\
\hline Expenditure (in \% of GDP) & -1.507 & $-4.648 * *$ & $-8.555^{* *}$ & -1.990 & $-3.388(*)$ & $-8.656 * *$ \\
\hline Revenue (in \% of GDP) & -1.571 & $-4.085^{* *}$ & $-19.539 * *$ & -1.252 & $-4.547 * *$ & $-19.100 * *$ \\
\hline \multicolumn{7}{|c|}{$1849-1939$} \\
\hline Budget Surplus (in \% of GDP) & $-2.836(*)$ & -3.109 & $-7.852 * *$ & $-2.888(*)$ & -3.036 & $-7.801 * *$ \\
\hline Public Debt (in \% of GDP) & -0.882 & -2.022 & $-5.841 * *$ & 0.285 & -1.542 & $-5.753 * *$ \\
\hline Expenditure (in \% of GDP) & -1.061 & $-3.633^{*}$ & $-7.382 * *$ & -0.939 & $-3.269(*)$ & $-7.330 * *$ \\
\hline Revenue (in \% of GDP) & -1.388 & -2.962 & $-7.924 * *$ & -0.985 & $-3.974 * *$ & $-7.382 * *$ \\
\hline \multicolumn{7}{|c|}{$1946-2007$} \\
\hline Budget Surplus (in \% of GDP) & $-3.469 *$ & $-3.506 *$ & $-11.558 * *$ & $-3.381 *$ & $-3.923 *$ & $-11.631^{* *}$ \\
\hline Public Debt (in \% of GDP) & $-4.106 * *$ & $-3.554 *$ & $-7.066 * *$ & $-3.780 * *$ & $-3.633^{*}$ & $-7.051^{* *}$ \\
\hline Expenditure (in \% of GDP) & -2.086 & $-5.061 * *$ & $-9.376^{* *}$ & -2.332 & $-6.192 * *$ & $-7.330 * *$ \\
\hline Revenue (in \% of GDP) & -2.197 & -2.933 & $-18.003^{* *}$ & -1.607 & $-4.823^{* *}$ & $-16.075^{* *}$ \\
\hline
\end{tabular}

The values are the estimated t-statistics. '**', '*' or ' (*)' indicate that the null hypothesis of a unit root can be rejected at the 1 , 5 , or 10 percent level, respectively. The number of lags of the ADF tests has been determined using the Hannan-Quinn criterion. For the Philipps-Perron tests always 4 lags have been used.

As Table 1 indicates, the hypothesis of a unit root in levels can be rejected for the federal budget surplus in percent of GDP for the whole time period from 1849 to 2007 on the one percent significance level, but also for the two sub-periods, 1849 to 1939 and 1946 to 2007, at the ten and five percent levels respectively. This holds irrespective of which test, the ADF or the PP test, is used. While the result for the whole time period is in line with that of Kirchgässner and 
Prohl (2008), the results for the sub-periods are stronger. In addition, the hypothesis of a unit root can be rejected for the level of federal debt in percent of GDP in the sub-period 1946 to 2007. Otherwise, the test statistics indicate that only first differences are stationary. In particular for federal spending and revenue, the hypothesis of a unit root in the levels could never be rejected for any period. However, as the results for the ADF-test as well as the PP-test suggest, government spending and revenue seem to be trend stationary. In the case for government debt, at least the period after World War II is trend stationary.

Table 2 Results of the Engle-Granger Cointegration Test, Swiss Federal Level, 1849 - 2007

\begin{tabular}{|c|c|c|c|c|}
\hline \multirow[b]{2}{*}{ Dependent Variable } & \multicolumn{2}{|c|}{ Cointegrating equation } & \multicolumn{2}{|c|}{ Residual regression } \\
\hline & $\begin{array}{l}\text { Coefficient } \\
\text { (S.E.) }\end{array}$ & $\mathrm{R}^{2}$ & $\begin{array}{l}\text { ADF } \\
\text { statistic }\end{array}$ & PP statistic \\
\hline \multicolumn{5}{|c|}{$1849-2007$} \\
\hline Expenditure-GDP-ratio & $\begin{array}{l}1.100 \\
(0.03)\end{array}$ & 0.868 & $-5.857 * *$ & $-6.030 * *$ \\
\hline Revenue-GDP-ratio & $\begin{array}{l}0.789 \\
(0.02) \\
\end{array}$ & 0.868 & $-5.897 * *$ & $-6.027 * *$ \\
\hline \multicolumn{5}{|c|}{$1849-1939$} \\
\hline Expenditure-GDP-ratio & $\begin{array}{l}0.901 \\
(0.07)\end{array}$ & 0.643 & $-4.720 * *$ & $-4.789 * *$ \\
\hline Revenue-GDP-ratio & $\begin{array}{l}0.714 \\
(0.06)\end{array}$ & 0.643 & $-5.432 * *$ & $-5.395^{* *}$ \\
\hline \multicolumn{5}{|c|}{$1946-2007$} \\
\hline Expenditure-GDP-ratio & $\begin{array}{l}1.083 \\
(0.08)\end{array}$ & 0.760 & $-5.798 * *$ & $-5.965^{* *}$ \\
\hline Revenue-GDP-ratio & $\begin{array}{l}0.701 \\
(0.05)\end{array}$ & 0.760 & $-5.326 * *$ & $-5.250 * *$ \\
\hline
\end{tabular}

'**', '*' or ' (*)' indicate that the null hypothesis of no cointegration can be rejected at the 1,5 , or 10 percent level, respectively. For the ADF tests 1 lag has always been used. For the Philipps-Perron tests always 4 lags have been used. The critical values for the ADF- and the PP-statistics of expenditure and revenue to GDP rations are -3.491 for the 1 percent level, -2.886 for the 5 percent level and -2.576 for the 10 percent level.

Given that the levels of budget surpluses in percent of GDP are I(0) and of the federal debt ratio is I(1) for the whole time period and before the Second World War, one of the usual tests for sustainability, namely that deficits and debt are cointegrated, would not make sense and could not serve as a help for our subsequent econometric specification. Thus, only tests on cointegration of federal spending and revenue are performed as they are difference stationary with the same order of integration. Table 2 presents the results of the residual based EngleGranger test for cointegration. The ADF test of the residuals for the whole time period gives a 
t-statistic of 5.9 which is significant at the 1 percent level. This indicates that federal revenue and expenditure in percent of GDP are cointegrated for the whole time period. Similarly high t-statistics for the two sub-periods could be observed such that cointegration between federal spending and revenue prevails consistently. Again our results for the sub-periods are stronger than those presented by Kirchgässner and Prohl (2008).

Table 3 Results of the Johansen Cointegration Test, Swiss Federal Level, 1849 - 2007

\begin{tabular}{|c|c|c|c|}
\hline Eigenvalue & Null hypothesis & Lags & Trace statistic \\
\hline \multicolumn{4}{|c|}{$1849-2007$} \\
\hline 0.145 & $r=0$ & 4 & $24.60 * *$ \\
\hline 0.002 & $r=1$ & 4 & 0.25 \\
\hline \multicolumn{4}{|c|}{$1849-1939$} \\
\hline 0.050 & $r=0$ & 4 & $4.55^{*}$ \\
\hline 0.002 & $r=1$ & 4 & 0.18 \\
\hline \multicolumn{4}{|c|}{$1946-2007$} \\
\hline 0.260 & $r=0$ & 4 & $21.51 * *$ \\
\hline 0.050 & $r=1$ & 4 & 3.13 \\
\hline
\end{tabular}

Finally, we use the Johansen multivariate cointegration test in order to determine the number of cointegrating vectors in the system. We perform the trace test only and assume the existence of a constant in the error correction term. Table 3 shows the results for the whole sample and the two sub-samples. The null hypothesis of no cointegration can be rejected for the whole time period and for the sub-period from 1946 to 2007 on the 1 percent level as well as for the sub-period from 1849 to 1939 on the 5 percent significance level. These results support the previous findings and the hypothesis that federal spending and revenue are cointegrated.

\section{Multivariate analysis}

For the multivariate analysis, these clear-cut results suggest the following strategy. As the federal budget surplus in percent of GDP is stationary for the whole time period and both subperiods, the model formulated before is estimated by OLS. As we could not establish any cointegrating relation between the federal debt ratio and economic or fiscal variables and as the federal debt ratio is even stationary for the time after the Second World War, the model is again estimated by OLS. In the case of federal debt to GDP, regressions for the levels and the first differences are presented. In both sets of regressions capturing indebtedness, the results including a one period lagged endogenous variable are presented. 
Table 4: Results for Federal Budget Surplus, in \% of GDP, 1849-2007

\begin{tabular}{|c|c|c|c|c|c|c|}
\hline \multirow[t]{3}{*}{\begin{tabular}{|l} 
Variables \\
\end{tabular}} & \multicolumn{6}{|c|}{ Budget Surplus in \% of GDP } \\
\hline & \multicolumn{4}{|c|}{ Full Sample } & \multicolumn{2}{|c|}{ Subsamples } \\
\hline & $\begin{array}{l}\text { Huber- } \\
\text { White- } \\
\text { Sandwich }\end{array}$ & $\begin{array}{l}\text { Newey- } \\
\text { West } \\
\text { (lag five } \\
\text { years) }\end{array}$ & $\begin{array}{l}\text { Lagged } \\
\text { Endo- } \\
\text { genous }\end{array}$ & $\begin{array}{c}\text { Prais- } \\
\text { Winsten } \\
\text { AR (1) }\end{array}$ & $\begin{array}{l}\text { Without wars, } \\
\text { Lagged } \\
\text { Endogenous }\end{array}$ & $\begin{array}{c}\text { Without wars, } \\
\text { recession 90/97, } \\
\text { Lagged } \\
\text { Endogenous }\end{array}$ \\
\hline Oil Price t-1 & $\begin{array}{l}0.010 \\
(0.27)\end{array}$ & $\begin{array}{l}0.010 \\
(0.21)\end{array}$ & $\begin{array}{l}0.021 \\
(0.71)\end{array}$ & $\begin{array}{l}0.016 \\
(0.32)\end{array}$ & $\begin{array}{l}0.011 \\
(0.51)\end{array}$ & $\begin{array}{l}-0.001 \\
(0.58)\end{array}$ \\
\hline Real GDP t-1 & $\begin{array}{l}-0.014(*) \\
(1.69)\end{array}$ & $\begin{array}{l}-0.014 \\
(1.31)\end{array}$ & $\begin{array}{l}-0.021^{*} \\
(2.37)\end{array}$ & $\begin{array}{l}-0.007 \\
(0.64)\end{array}$ & $\begin{array}{l}-0.006(*) \\
(1.74)\end{array}$ & $\begin{array}{l}-0.006 \\
(-1.47)\end{array}$ \\
\hline Population t-1 & $\begin{array}{l}0.002 * \\
(2.04)\end{array}$ & $\begin{array}{l}0.003 \\
(1.51)\end{array}$ & $\begin{array}{l}0.004^{*} \\
(2.53)\end{array}$ & $\begin{array}{l}0.003 \\
(1.39)\end{array}$ & $\begin{array}{l}0.001 \\
(1.42)\end{array}$ & $\begin{array}{l}0.001 \\
(1.27)\end{array}$ \\
\hline Wars & $\begin{array}{l}-4.234^{* *} \\
(4.85)\end{array}$ & $\begin{array}{l}-4.237^{* *} \\
(3.80)\end{array}$ & $\begin{array}{l}-2.611^{* *} \\
(4.03)\end{array}$ & $\begin{array}{l}-2.727 * * \\
(3.52)\end{array}$ & - & - \\
\hline Great Depression & $\begin{array}{l}1.792^{* *} \\
(3.20)\end{array}$ & $\begin{array}{l}1.792^{* *} \\
(3.19)\end{array}$ & $\begin{array}{l}0.766\left(^{*}\right) \\
(1.68)\end{array}$ & $\begin{array}{l}0.703 \\
(1.29)\end{array}$ & $\begin{array}{l}0.433 \\
(1.21)\end{array}$ & $\begin{array}{l}0.544 \\
(1.50)\end{array}$ \\
\hline Tax Amnesty & $\begin{array}{l}-2.521\left(^{*}\right) \\
(1.72)\end{array}$ & $\begin{array}{l}-2.521 * \\
(2.07)\end{array}$ & $\begin{array}{l}-2.745 \\
(1.59)\end{array}$ & $\begin{array}{l}-1.946 \\
(1.12)\end{array}$ & $\begin{array}{l}-1.261 \\
(0.89)\end{array}$ & $\begin{array}{l}-1.591 \\
(1.20)\end{array}$ \\
\hline Existence SNB & $\begin{array}{l}0.003 \\
(0.60)\end{array}$ & $\begin{array}{l}0.003 \\
(0.56)\end{array}$ & $\begin{array}{l}-0.004 \\
(1.17)\end{array}$ & $\begin{array}{l}-0.007 \\
(0.13)\end{array}$ & $\begin{array}{l}-0.018 \\
(0.91)\end{array}$ & $\begin{array}{l}-0.031 \\
(1.47)\end{array}$ \\
\hline Devaluation & $\begin{array}{l}1.674^{* *} \\
(4.50)\end{array}$ & $\begin{array}{l}1.674 * * \\
(3.73)\end{array}$ & $\begin{array}{l}1.211 * * \\
(3.67)\end{array}$ & $\begin{array}{l}0.628 \\
(1.44)\end{array}$ & $\begin{array}{l}0.840^{* *} \\
(3.19)\end{array}$ & $\begin{array}{l}0.841^{* *} \\
(3.16)\end{array}$ \\
\hline $\begin{array}{l}\text { State Old Age Pension } \\
\text { System (AHV) }\end{array}$ & $\begin{array}{l}1.453^{*} \\
(2.23)\end{array}$ & $\begin{array}{l}1.453(*) \\
(1.69)\end{array}$ & $\begin{array}{l}0.685 \\
(0.85)\end{array}$ & $\begin{array}{l}0.736 \\
(0.98)\end{array}$ & $\begin{array}{l}-0.279 \\
(0.72)\end{array}$ & $\begin{array}{l}-0.268 \\
(0.68)\end{array}$ \\
\hline $\begin{array}{l}\text { Proportional } \\
\text { Representation }\end{array}$ & $\begin{array}{l}-2.463^{*} \\
(2.48)\end{array}$ & $\begin{array}{l}-2.463 * \\
(2.26)\end{array}$ & $\begin{array}{l}-1.514^{*} \\
(2.50)\end{array}$ & $\begin{array}{l}-1.257 \\
(1.17)\end{array}$ & $\begin{array}{l}0.279 \\
(0.72)\end{array}$ & $\begin{array}{l}0.212 \\
(0.54)\end{array}$ \\
\hline $\begin{array}{l}\text { Time Horizon of } \\
\text { Finance Minister t-1 }\end{array}$ & $\begin{array}{l}0.076^{* *} \\
(2.85)\end{array}$ & $\begin{array}{l}0.076^{*} \\
(2.28)\end{array}$ & $\begin{array}{l}0.053^{*} \\
(2.34)\end{array}$ & $\begin{array}{l}0.029 \\
(1.32)\end{array}$ & $\begin{array}{l}0.032 * \\
(2.06)\end{array}$ & $\begin{array}{l}0.025\left(^{*}\right) \\
(1.72)\end{array}$ \\
\hline $\begin{array}{l}\text { Number of Referenda } \\
\text { and Initiatives t-1 }\end{array}$ & $\begin{array}{l}-0.132\left(^{*}\right) \\
(1.93)\end{array}$ & $\begin{array}{l}-0.132 * \\
(2.49)\end{array}$ & $\begin{array}{l}-0.118\left(^{*}\right) \\
(1.76)\end{array}$ & $\begin{array}{l}-0.047 \\
(0.91)\end{array}$ & $\begin{array}{l}-0.083(*) \\
(1.79)\end{array}$ & $\begin{array}{l}-0.080\left(^{*}\right) \\
(1.72)\end{array}$ \\
\hline Turnout t-1 & $\begin{array}{l}0.056 \\
(0.10)\end{array}$ & $\begin{array}{l}0.056 \\
(0.11)\end{array}$ & $\begin{array}{l}0.001 \\
(0.37)\end{array}$ & $\begin{array}{l}0.001 \\
(0.27)\end{array}$ & $\begin{array}{l}0.001 \\
(0.59)\end{array}$ & $\begin{array}{l}0.002 \\
(0.90)\end{array}$ \\
\hline $\begin{array}{l}\text { Social Democratic } \\
\text { Finance Minister t-1 }\end{array}$ & $\begin{array}{l}0.890^{*} \\
(2.28)\end{array}$ & $\begin{array}{l}0.890 \\
(1.48)\end{array}$ & $\begin{array}{l}1.039 * \\
(2.37)\end{array}$ & $\begin{array}{l}0.012^{*} \\
(2.38)\end{array}$ & $\begin{array}{l}0.027 \\
(1.25)\end{array}$ & $\begin{array}{l}0.043(*) \\
(1.90)\end{array}$ \\
\hline $\begin{array}{l}\text { Number of Seats of } \\
\text { Social Democrats in } \\
\text { Parliament t-1 }\end{array}$ & $\begin{array}{l}0.159 * * \\
(3.20)\end{array}$ & $\begin{array}{l}0.159^{*} \\
(2.25)\end{array}$ & $\begin{array}{l}0.115^{* *} \\
(3.13)\end{array}$ & $\begin{array}{l}0.144^{*} \\
(2.38)\end{array}$ & $\begin{array}{l}0.026 \\
(1.43)\end{array}$ & $\begin{array}{l}0.015 \\
(0.81)\end{array}$ \\
\hline $\begin{array}{l}\text { Surplus in \% of GDP } \\
\mathrm{t}-1\end{array}$ & - & - & $\begin{array}{l}0.492^{* *} \\
(3.03)\end{array}$ & - & $\begin{array}{l}0.266^{*} \\
(2.35)\end{array}$ & $\begin{array}{l}0.210\left(^{*}\right) \\
(1.94)\end{array}$ \\
\hline Interest rates $\mathrm{t}-1$ & $\begin{array}{l}-0.044^{* *} \\
(4.27)\end{array}$ & $\begin{array}{l}-0.044^{* *} \\
(3.96)\end{array}$ & $\begin{array}{l}-0.038^{* *} \\
(3.79)\end{array}$ & $\begin{array}{l}-0.054^{* *} \\
(3.44)\end{array}$ & $\begin{array}{l}-0.043^{* *} \\
(4.75)\end{array}$ & $\begin{array}{l}-0.038^{* *} \\
(4.26)\end{array}$ \\
\hline Federal income tax & $\begin{array}{l}-0.009 \\
(1.46)\end{array}$ & $\begin{array}{l}-0.009 \\
(1.06)\end{array}$ & $\begin{array}{l}0.003 \\
(0.08)\end{array}$ & $\begin{array}{l}-0.006 \\
(1.04)\end{array}$ & $\begin{array}{l}0.004 \\
(1.05)\end{array}$ & $\begin{array}{l}0.003 \\
(0.89)\end{array}$ \\
\hline Time Trend & $\begin{array}{l}-0.001^{* *} \\
(2.94)\end{array}$ & $\begin{array}{l}-0.001 * \\
(2.06)\end{array}$ & $\begin{array}{l}-0.001^{* *} \\
(3.00)\end{array}$ & $\begin{array}{l}-0.001 * \\
(2.07)\end{array}$ & $\begin{array}{l}-0.002(*) \\
(1.87)\end{array}$ & $\begin{array}{l}-0.002 \\
(1.50)\end{array}$ \\
\hline Constant & 1.430 & 1.430 & 1.447 & 1.656 & 0.391 & 0.344 \\
\hline Observations & 158 & 158 & 158 & 158 & 144 & 136 \\
\hline $\mathrm{R}^{2}$ & 0.720 & - & 0.809 & 0.413 & 0.580 & 0.488 \\
\hline D.W. (transformed) & 1.285 & - & 1.855 & 1.951 & 1.853 & 1.804 \\
\hline F-Test & - & $13.10^{* *}$ & - & - & - & - \\
\hline RMSE & 0.011 & & 0.009 & 0.010 & 0.052 & 0.0050 \\
\hline S.W. for normal data & $8.084^{* *}$ & $8.084^{* *}$ & $8.432 * *$ & $7.230^{* *}$ & $5.376^{* *}$ & $4.906 * *$ \\
\hline
\end{tabular}


Table 5: Results for Federal Debt, in \% of GDP, 1849-2007

\begin{tabular}{|c|c|c|c|c|c|c|}
\hline \multirow[t]{3}{*}{ Variables } & \multicolumn{6}{|c|}{ Public Debt in \% of GDP } \\
\hline & \multicolumn{3}{|c|}{ Level } & \multicolumn{3}{|c|}{ First Differences } \\
\hline & $\begin{array}{l}\text { Full } \\
\text { Sample }\end{array}$ & $\begin{array}{l}\text { Without } \\
\text { wars }\end{array}$ & $\begin{array}{c}\text { Without } \\
\text { wars, re- } \\
\text { cession 90/97 }\end{array}$ & Full Sample & $\begin{array}{l}\text { Without } \\
\text { wars }\end{array}$ & $\begin{array}{l}\text { Without wars } \\
\text { recession } \\
\text { 90/97 }\end{array}$ \\
\hline Oil Price t-1 & $\begin{array}{c}-0.001 \\
(0.23)\end{array}$ & $\begin{array}{c}-0.002 \\
(0.43)\end{array}$ & $\begin{array}{c}-0.001 \\
(0.21)\end{array}$ & $\begin{array}{c}-0.001 \\
(1.61)\end{array}$ & $\begin{array}{l}-0.001 \\
(0.13)\end{array}$ & $\begin{array}{l}-0.001 \\
(0.14)\end{array}$ \\
\hline Real GDP t-1 & $\begin{array}{l}0.002 \\
(1.35)\end{array}$ & $\begin{array}{l}0.001 \\
(0.83)\end{array}$ & $\begin{array}{l}0.002 \\
(1.29)\end{array}$ & $\begin{array}{l}-0.001\left(^{*}\right) \\
(1.97)\end{array}$ & $\begin{array}{l}-0.001 \\
(1.14)\end{array}$ & $\begin{array}{l}-0.001 \\
(0.91)\end{array}$ \\
\hline Population t-1 & $\begin{array}{l}-0.467 \\
(1.64)\end{array}$ & $\begin{array}{l}-0.165 \\
(0.67)\end{array}$ & $\begin{array}{l}-0.302 \\
(1.15)\end{array}$ & $\begin{array}{l}-0.714 \\
(1.08)\end{array}$ & $\begin{array}{l}-0.950 \\
(1.49)\end{array}$ & $\begin{array}{l}-0.100 \\
(1.50)\end{array}$ \\
\hline Wars & $\begin{array}{l}4.548 * * \\
(5.18)\end{array}$ & - & - & $\begin{array}{l}3.625^{* *} \\
(4.30)\end{array}$ & - & - \\
\hline Great Depression & $\begin{array}{l}0.508 \\
(0.54)\end{array}$ & $\begin{array}{l}0.016 \\
(1.66)\end{array}$ & $\begin{array}{l}0.014 \\
(1.44)\end{array}$ & $\begin{array}{l}0.008 \\
(0.98)\end{array}$ & $\begin{array}{l}0.017\left(^{*}\right) \\
(1.79)\end{array}$ & $\begin{array}{l}0.017\left(^{*}\right) \\
(1.78)\end{array}$ \\
\hline Tax Amnesty & $\begin{array}{l}0.221 \\
(0.11)\end{array}$ & $\begin{array}{l}-0.379 \\
(0.53)\end{array}$ & $\begin{array}{l}-0.212 \\
(0.29)\end{array}$ & $\begin{array}{l}-0.002 \\
(0.09)\end{array}$ & $\begin{array}{l}0.002 \\
(0.31)\end{array}$ & $\begin{array}{l}0.001 \\
(0.22)\end{array}$ \\
\hline Existence SNB & $\begin{array}{l}-0.995 \\
(0.12)\end{array}$ & $\begin{array}{l}0.180 \\
(0.30)\end{array}$ & $\begin{array}{l}0.602 \\
(0.94)\end{array}$ & $\begin{array}{l}-0.598 \\
(1.05)\end{array}$ & $\begin{array}{l}-0.002 \\
(0.55)\end{array}$ & $\begin{array}{l}-0.008 \\
(0.19)\end{array}$ \\
\hline Devaluation & $\begin{array}{l}3.046^{* *} \\
(4.52)\end{array}$ & $\begin{array}{l}3.520^{* *} \\
(5.01)\end{array}$ & $\begin{array}{l}3.531^{* *} \\
(5.02)\end{array}$ & $\begin{array}{l}3.124^{* *} \\
(4.91)\end{array}$ & $\begin{array}{l}3.542 * * \\
(5.03)\end{array}$ & $\begin{array}{l}3.611^{* *} \\
(5.00)\end{array}$ \\
\hline $\begin{array}{l}\text { State Old Age Pension } \\
\text { System (AHV) }\end{array}$ & $\begin{array}{l}1.011 \\
(0.59)\end{array}$ & $\begin{array}{l}2.275 \\
(1.30)\end{array}$ & $\begin{array}{l}2.588 \\
(1.49)\end{array}$ & $\begin{array}{l}0.641 \\
(0.48)\end{array}$ & $\begin{array}{l}2.404\left(^{*}\right) \\
(1.83)\end{array}$ & $\begin{array}{l}2.607\left(^{*}\right) \\
(1.94)\end{array}$ \\
\hline $\begin{array}{l}\text { Proportional } \\
\text { Representation }\end{array}$ & $\begin{array}{l}2.932 * \\
(2.21)\end{array}$ & $\begin{array}{l}-0.953 \\
(0.09)\end{array}$ & $\begin{array}{l}0.014 \\
(0.13)\end{array}$ & $\begin{array}{l}2.176^{*} \\
(2.17)\end{array}$ & $\begin{array}{l}-0.277 \\
(0.34)\end{array}$ & $\begin{array}{l}-0.475 \\
(0.58)\end{array}$ \\
\hline $\begin{array}{l}\text { Time Horizon of } \\
\text { Finance Minister } \\
\mathrm{t}-1\end{array}$ & $\begin{array}{l}-0.001 \\
(1.21)\end{array}$ & $\begin{array}{l}-0.001 \\
(0.22)\end{array}$ & $\begin{array}{l}-0.001 \\
(0.05)\end{array}$ & $\begin{array}{l}-0.001 \\
(0.37)\end{array}$ & $\begin{array}{l}0.001 \\
(0.22)\end{array}$ & $\begin{array}{l}0.001 \\
(0.48)\end{array}$ \\
\hline $\begin{array}{l}\text { Number of Referenda } \\
\text { and Initiatives t-1 }\end{array}$ & $\begin{array}{l}0.115 \\
(0.94)\end{array}$ & $\begin{array}{l}0.056 \\
(0.49)\end{array}$ & $\begin{array}{l}0.033 \\
(0.28)\end{array}$ & $\begin{array}{l}0.051 \\
(0.44)\end{array}$ & $\begin{array}{l}0.001 \\
(0.09)\end{array}$ & $\begin{array}{l}0.002 \\
(0.01)\end{array}$ \\
\hline Turnout t-1 & $\begin{array}{l}-0.001 \\
(0.12)\end{array}$ & $\begin{array}{l}0.001 \\
(0.43)\end{array}$ & $\begin{array}{l}0.001 \\
(0.45)\end{array}$ & $\begin{array}{l}0.001 \\
(0.50)\end{array}$ & $\begin{array}{l}0.001 \\
(0.65)\end{array}$ & $\begin{array}{l}0.001 \\
(0.62)\end{array}$ \\
\hline $\begin{array}{l}\text { Social Democratic } \\
\text { Finance Minister t-1 }\end{array}$ & $\begin{array}{l}-0.022^{* *} \\
(2.73)\end{array}$ & $\begin{array}{l}-0.010 \\
(1.51)\end{array}$ & $\begin{array}{l}-0.012\left(^{*}\right) \\
(1.70)\end{array}$ & $\begin{array}{l}-0.017^{*} \\
(2.30)\end{array}$ & $\begin{array}{l}-0.010 \\
(1.48)\end{array}$ & $\begin{array}{l}-0.012(*) \\
(1.67)\end{array}$ \\
\hline $\begin{array}{l}\text { Number of Seats of } \\
\text { Social Democrats in } \\
\text { Parliament t-1 }\end{array}$ & $\begin{array}{l}-0.222^{* *} \\
(2.87)\end{array}$ & $\begin{array}{l}-0.045 \\
(0.79)\end{array}$ & $\begin{array}{l}-0.045 \\
(0.78)\end{array}$ & $\begin{array}{l}-0.165^{* *} \\
(3.19)\end{array}$ & $\begin{array}{l}-0.061(*) \\
(1.66)\end{array}$ & $\begin{array}{l}-0.043 \\
(1.18)\end{array}$ \\
\hline $\begin{array}{l}\text { Debt in \% of GDP } \\
\mathrm{t}-1\end{array}$ & $\begin{array}{l}0.973 * * \\
(22.71)\end{array}$ & $\begin{array}{l}0.975^{* *} \\
(24.54)\end{array}$ & $\begin{array}{l}0.963^{* *} \\
(23.89)\end{array}$ & $\begin{array}{l}0.112 \\
(0.85)\end{array}$ & $\begin{array}{l}0.052 \\
(0.36)\end{array}$ & $\begin{array}{l}0.0247 \\
(0.16)\end{array}$ \\
\hline Interest rates $\mathrm{t}-1$ & $\begin{array}{l}0.010^{* *} \\
(4.09)\end{array}$ & $\begin{array}{l}0.011^{* *} \\
(4.52)\end{array}$ & $\begin{array}{l}0.010^{* *} \\
(3.84)\end{array}$ & $\begin{array}{l}0.005\left(^{*}\right) \\
(1.78)\end{array}$ & $\begin{array}{l}0.008^{* *} \\
(2.73)\end{array}$ & $\begin{array}{l}0.008^{*} \\
(2.32)\end{array}$ \\
\hline Federal income tax & $\begin{array}{l}-0.007 \\
(0.70)\end{array}$ & $\begin{array}{l}-0.023 * \\
(1.99)\end{array}$ & $\begin{array}{l}-0.021(*) \\
(1.87)\end{array}$ & $\begin{array}{l}-0.007 \\
(0.93)\end{array}$ & $\begin{array}{l}-0.021\left(^{*}\right) \\
(1.83)\end{array}$ & $\begin{array}{l}-0.022(*) \\
(1.84)\end{array}$ \\
\hline Time Trend & $\begin{array}{l}0.001^{*} \\
(2.36)\end{array}$ & $\begin{array}{l}0.001 \\
(0.88)\end{array}$ & $\begin{array}{l}0.001 \\
(1.27)\end{array}$ & $\begin{array}{l}0.001\left(^{*}\right) \\
(1.77)\end{array}$ & $\begin{array}{l}0.001 \\
(1.22)\end{array}$ & $\begin{array}{l}0.001 \\
(0.91)\end{array}$ \\
\hline Constant & -2.206 & -0.715 & -1.055 & -0.490 & -0.357 & -0.272 \\
\hline Observations & 158 & 144 & 136 & 157 & 143 & 135 \\
\hline $\mathrm{R}^{2}$ & 0.985 & 0.985 & 0.985 & 0.500 & 0.464 & 0.442 \\
\hline D.W. (transformed) & 1.829 & 1.963 & 1.982 & 2.083 & 2.105 & 2.064 \\
\hline RMSE & 0.018 & 0.016 & 0.016 & 0.018 & 0.015 & 0.016 \\
\hline S.W. for normal data & $5.919 * *$ & $5.889 * *$ & $5.878^{* *}$ & $4.795^{* *}$ & $.538 * *$ & $5.718^{* *}$ \\
\hline
\end{tabular}


Table 6: Error Correction Model for Federal Spending and Revenue, in \% of GDP, 1849-2007

\begin{tabular}{|c|c|c|c|c|c|c|}
\hline \multirow[t]{2}{*}{ Variables } & \multicolumn{3}{|c|}{ First Difference in Expenditure } & \multicolumn{3}{|c|}{ First Difference in Revenue } \\
\hline & Full Sample & Without wars & $\begin{array}{l}\text { Without wars, } \\
\text { recession } \\
90 / 97\end{array}$ & Full Sample & Without wars & $\begin{array}{l}\text { Without wars, } \\
\text { recession } \\
90 / 97\end{array}$ \\
\hline Oil Price t-1 & $\begin{array}{l}-0.015 \\
(0.71)\end{array}$ & $\begin{array}{l}-0.019 \\
(1.14)\end{array}$ & $\begin{array}{l}-0.009 \\
(0.61)\end{array}$ & $\begin{array}{l}-0.004 \\
(1.58)\end{array}$ & $\begin{array}{l}-0.003(*) \\
(1.76)\end{array}$ & $\begin{array}{l}-0.003 \\
(1.51)\end{array}$ \\
\hline Real GDP t-1 & $\begin{array}{l}0.012^{* *} \\
(3.00)\end{array}$ & $\begin{array}{l}0.054^{*} \\
(1.99)\end{array}$ & $\begin{array}{l}0.037 \\
(1.24)\end{array}$ & $\begin{array}{l}0.075\left(^{*}\right) \\
(1.76)\end{array}$ & $\begin{array}{l}0.093 \\
(0.28)\end{array}$ & $\begin{array}{l}0.003 \\
(0.99)\end{array}$ \\
\hline Population t-1 & $\begin{array}{l}-0.002 * * \\
(3.14)\end{array}$ & $\begin{array}{l}-0.008 \\
(1.64)\end{array}$ & $\begin{array}{l}-0.005 \\
(1.05)\end{array}$ & $\begin{array}{l}-0.001 \\
(1.64)\end{array}$ & $\begin{array}{l}-0.002 \\
(0.00)\end{array}$ & $\begin{array}{l}-0.004 \\
(0.74)\end{array}$ \\
\hline Wars & $\begin{array}{l}0.013^{*} \\
(2.50)\end{array}$ & - & - & $\begin{array}{l}0.015^{*} \\
(2.00)\end{array}$ & - & - \\
\hline Great Depression & $\begin{array}{l}-0.467 \\
(1.19)\end{array}$ & $\begin{array}{l}0.209 \\
(0.01)\end{array}$ & $\begin{array}{l}-0.060 \\
(0.00)\end{array}$ & $\begin{array}{l}-0.124 \\
(0.28)\end{array}$ & $\begin{array}{l}0.035 \\
(1.25)\end{array}$ & $\begin{array}{l}0.031 \\
(1.12)\end{array}$ \\
\hline Tax Amnesty & $\begin{array}{l}0.010 \\
(1.14)\end{array}$ & $\begin{array}{l}0.025^{*} \\
(2.08)\end{array}$ & $\begin{array}{l}0.022\left(^{*}\right) \\
(1.94)\end{array}$ & $\begin{array}{l}0.050 \\
(0.76)\end{array}$ & $\begin{array}{l}-0.022 \\
(1.53)\end{array}$ & $\begin{array}{l}-0.011 \\
(0.95)\end{array}$ \\
\hline Existence SNB & $\begin{array}{l}0.324 \\
(1.23)\end{array}$ & $\begin{array}{l}0.172 \\
(1.08)\end{array}$ & $\begin{array}{l}0.002 \\
(1.26)\end{array}$ & $\begin{array}{l}-0.931^{*} \\
(2.06)\end{array}$ & $\begin{array}{l}-0.658(*) \\
(1.74)\end{array}$ & $\begin{array}{l}-0.006 \\
(1.56)\end{array}$ \\
\hline Devaluation & $\begin{array}{l}-0.581^{*} \\
(2.02)\end{array}$ & $\begin{array}{l}-0.016 \\
(0.83)\end{array}$ & $\begin{array}{l}-0.016 \\
(0.83)\end{array}$ & $\begin{array}{l}-0.006 \\
(1.35)\end{array}$ & $\begin{array}{l}-0.064 \\
(0.04)\end{array}$ & $\begin{array}{l}0.048 \\
(0.29)\end{array}$ \\
\hline $\begin{array}{l}\text { State Old Age Pension } \\
\text { System(AHV) }\end{array}$ & $\begin{array}{l}0.226 \\
(0.50)\end{array}$ & $\begin{array}{l}0.581(*) \\
(1.76)\end{array}$ & $\begin{array}{l}0.551 \\
(1.64)\end{array}$ & $\begin{array}{l}0.429 \\
(0.89)\end{array}$ & $\begin{array}{l}0.057 \\
(1.65)\end{array}$ & $\begin{array}{l}0.073(*) \\
(1.95)\end{array}$ \\
\hline $\begin{array}{l}\text { Proportional } \\
\text { Representation }\end{array}$ & $\begin{array}{l}0.625 \\
(1.17)\end{array}$ & $\begin{array}{l}-0.002 \\
(0.86)\end{array}$ & $\begin{array}{l}-0.003 \\
(1.06)\end{array}$ & $\begin{array}{l}0.186^{*} \\
(1.98)\end{array}$ & $\begin{array}{l}0.004 \\
(0.69)\end{array}$ & $\begin{array}{l}0.004 \\
(0.83)\end{array}$ \\
\hline $\begin{array}{l}\text { Time Horizon of Fi- } \\
\text { nance Minister t-1 }\end{array}$ & $\begin{array}{l}-0.031^{*} \\
(2.05)\end{array}$ & $\begin{array}{l}-0.019(*) \\
(1.80)\end{array}$ & $\begin{array}{l}-0.015 \\
(1.50)\end{array}$ & $\begin{array}{l}-0.004(*) \\
(1.72)\end{array}$ & $\begin{array}{l}-0.001 \\
(0.83)\end{array}$ & $\begin{array}{l}-0.001 \\
(0.73)\end{array}$ \\
\hline $\begin{array}{l}\text { Number of Referenda } \\
\text { and Initiatives t-1 }\end{array}$ & $\begin{array}{l}0.052 \\
(1.11)\end{array}$ & $\begin{array}{l}0.018 \\
(0.59)\end{array}$ & $\begin{array}{l}0.0024 \\
(0.79)\end{array}$ & $\begin{array}{l}0.013^{*} \\
(2.21)\end{array}$ & $\begin{array}{l}0.041 \\
(1.30)\end{array}$ & $\begin{array}{l}0.026 \\
(0.95)\end{array}$ \\
\hline Turnout t-1 & $\begin{array}{l}0.042 \\
(0.15)\end{array}$ & $\begin{array}{l}-0.010 \\
(0.48)\end{array}$ & $\begin{array}{l}-0.015 \\
(0.69)\end{array}$ & $\begin{array}{l}-0.002 \\
(0.70)\end{array}$ & $\begin{array}{l}0.003 \\
(0.11)\end{array}$ & $\begin{array}{l}0.008 \\
(0.28)\end{array}$ \\
\hline $\begin{array}{l}\text { Social Democratic } \\
\text { Finance Minister t-1 }\end{array}$ & $\begin{array}{l}-0.048^{*} \\
(2.09)\end{array}$ & $\begin{array}{l}-0.021 \\
(1.21)\end{array}$ & $\begin{array}{l}-0.003 \\
(1.40)\end{array}$ & $\begin{array}{l}-0.002 \\
(0.65)\end{array}$ & $\begin{array}{l}0.001 \\
(0.62)\end{array}$ & $\begin{array}{l}0.005 \\
(0.30)\end{array}$ \\
\hline $\begin{array}{l}\text { Number of Seats of } \\
\text { Social Democrats in } \\
\text { Parliament t-1 }\end{array}$ & $\begin{array}{l}-0.049^{*} \\
(2.04)\end{array}$ & $\begin{array}{l}-0.010 \\
(0.66)\end{array}$ & $\begin{array}{l}-0.036 \\
(0.23)\end{array}$ & $\begin{array}{l}-0.044 \\
(1.25)\end{array}$ & $\begin{array}{l}0.005 \\
(0.26)\end{array}$ & $\begin{array}{l}0.002 \\
(0.09)\end{array}$ \\
\hline $\begin{array}{l}\text { Change in Expenditure } \\
\text { in \% of GDP t-1 }\end{array}$ & $\begin{array}{l}0.179 * \\
(2.03)\end{array}$ & $\begin{array}{l}-0.066 \\
(0.81)\end{array}$ & $\begin{array}{l}-0.089 \\
(1.00)\end{array}$ & $\begin{array}{l}0.065 \\
(0.66)\end{array}$ & $\begin{array}{l}0.165\left(^{*}\right) \\
(1.84)\end{array}$ & $\begin{array}{l}0.143\left(^{*}\right) \\
(1.70)\end{array}$ \\
\hline $\begin{array}{l}\text { Change in Revenue in } \\
\% \text { of GDP } t-1\end{array}$ & $\begin{array}{l}0.288\left(^{*}\right) \\
(1.96)\end{array}$ & $\begin{array}{l}0.001 \\
(0.01)\end{array}$ & $\begin{array}{l}-0.024 \\
(0.26)\end{array}$ & $\begin{array}{l}-0.300^{*} \\
(2.10)\end{array}$ & $\begin{array}{l}-0.405^{* *} \\
(3.45)\end{array}$ & $\begin{array}{l}-0.356^{* *} \\
(2.84)\end{array}$ \\
\hline $\begin{array}{l}\text { Expenditure in \% of } \\
\text { GDP t-1 }\end{array}$ & $\begin{array}{l}-0.302 * * \\
(3.60)\end{array}$ & $\begin{array}{l}-0.362 * * \\
(7.03)\end{array}$ & $\begin{array}{l}-0.379 * * \\
(6.97)\end{array}$ & $\begin{array}{l}0.096 \\
(0.79)\end{array}$ & $\begin{array}{l}0.071 \\
(1.01)\end{array}$ & $\begin{array}{l}0.074 \\
(1.02)\end{array}$ \\
\hline $\begin{array}{l}\text { Revenue in \% of GDP } \\
\mathrm{t}-1\end{array}$ & $\begin{array}{l}0.270^{*} \\
(2.16)\end{array}$ & $\begin{array}{l}0.328 * * \\
(3.73)\end{array}$ & $\begin{array}{l}0.356^{* *} \\
(3.85)\end{array}$ & $\begin{array}{l}-0.524 * * \\
(2.98)\end{array}$ & $\begin{array}{l}-0.400 * * \\
(3.02)\end{array}$ & $\begin{array}{l}-0.450 * * \\
(3.26)\end{array}$ \\
\hline Interest rates $\mathrm{t}-1$ & $\begin{array}{l}0.017^{*} \\
(2.16)\end{array}$ & $\begin{array}{l}0.003^{* *} \\
(3.88)\end{array}$ & $\begin{array}{l}0.002 * * \\
(3.12)\end{array}$ & $\begin{array}{l}-0.004 \\
(0.36)\end{array}$ & $\begin{array}{l}0.003 \\
(0.49)\end{array}$ & $\begin{array}{l}0.001 \\
(0.13)\end{array}$ \\
\hline Federal income tax & $\begin{array}{l}-0.001 \\
(0.01)\end{array}$ & $\begin{array}{l}-0.004 \\
(1.49)\end{array}$ & $\begin{array}{l}-0.005 \\
(1.56)\end{array}$ & $\begin{array}{l}-0.004 \\
(1.07)\end{array}$ & $\begin{array}{l}-0.003 \\
(1.33)\end{array}$ & $\begin{array}{l}-0.003 \\
(1.06)\end{array}$ \\
\hline Time Trend & $\begin{array}{l}0.004^{* *} \\
(3.10)\end{array}$ & $\begin{array}{l}0.001^{*} \\
(2.25)\end{array}$ & $\begin{array}{l}0.001 \\
(1.44)\end{array}$ & $\begin{array}{l}0.005^{* *} \\
(2.96)\end{array}$ & $\begin{array}{l}0.002\left(^{*}\right) \\
(1.67)\end{array}$ & $\begin{array}{l}0.003^{*} \\
(2.21)\end{array}$ \\
\hline Constant & -0.740 & -0.347 & -0.247 & -0.923 & -0.346 & -0.486 \\
\hline Observations & 157 & 143 & 135 & 157 & 143 & 135 \\
\hline $\mathrm{R}^{2}$ & 0.646 & 0.615 & 0.611 & 0.491 & 0.548 & 0.560 \\
\hline D.W. (transformed) & 1.835 & 2.022 & 2.028 & 1.986 & 1.595 & 1.631 \\
\hline RMSE & 0.006 & 0.004 & 0.004 & 0.007 & 0.005 & 0.004 \\
\hline S.W. for normal data & $7.667 * *$ & $8.574 * *$ & $8.664 * *$ & $5.297 * *$ & $8.075 * *$ & $8.151 * *$ \\
\hline
\end{tabular}


Table 7: Results for Federal Spending and Revenue, in \% of GDP, 1849-2007

\begin{tabular}{|c|c|c|c|c|c|c|}
\hline \multirow[t]{2}{*}{ Variables } & \multicolumn{3}{|c|}{ Level for Expenditure } & \multicolumn{3}{|c|}{ Level for Revenue } \\
\hline & $\begin{array}{l}\text { Robust } \\
\text { Standard } \\
\text { Errors }\end{array}$ & $\begin{array}{c}\text { Lagged } \\
\text { Endogenous }\end{array}$ & $\begin{array}{l}\text { Prais- } \\
\text { Winsten } \\
\text { AR (1) }\end{array}$ & $\begin{array}{l}\text { Robust } \\
\text { Standard } \\
\text { Errors }\end{array}$ & $\begin{array}{c}\text { Lagged } \\
\text { Endogenous }\end{array}$ & $\begin{array}{l}\text { Prais- } \\
\text { Winsten } \\
\text { AR (1) }\end{array}$ \\
\hline Oil Price t-1 & $\begin{array}{l}-0.0001 \\
(1.44)\end{array}$ & $\begin{array}{l}-0.0001 \\
(1.42)\end{array}$ & $\begin{array}{l}0.000 \\
(0.19)\end{array}$ & $\begin{array}{l}-0.0001 * \\
(2.19)\end{array}$ & $\begin{array}{l}-0.0005(*) \\
(1.66)\end{array}$ & $\begin{array}{l}0.000 \\
(0.06)\end{array}$ \\
\hline Real GDP t-1 & $\begin{array}{l}0.0001 \\
(0.79)\end{array}$ & $\begin{array}{l}0.0002 * \\
(2.50)\end{array}$ & $\begin{array}{l}-0.0001 \\
(1.06)\end{array}$ & $\begin{array}{l}0.0001 \\
(1.22)\end{array}$ & $\begin{array}{l}0.0004 \\
(0.74)\end{array}$ & $\begin{array}{l}0.00001 \\
(0.11)\end{array}$ \\
\hline Population t-1 & $\begin{array}{l}0.000 \\
(0.78)\end{array}$ & $\begin{array}{l}0.000^{*} \\
(2.61)\end{array}$ & $\begin{array}{l}-0.000 \\
(0.72)\end{array}$ & $\begin{array}{l}-0.000 \\
(0.95)\end{array}$ & $\begin{array}{l}-0.000 \\
(0.46)\end{array}$ & $\begin{array}{l}-0.000 \\
(0.17)\end{array}$ \\
\hline Wars & $\begin{array}{l}0.041^{* *} \\
(3.96)\end{array}$ & $\begin{array}{l}0.018^{* *} \\
(3.93)\end{array}$ & $\begin{array}{l}0.014^{* *} \\
(3.40)\end{array}$ & $\begin{array}{l}0.023 * * \\
(3.74)\end{array}$ & $\begin{array}{l}0.017^{*} \\
(2.39)\end{array}$ & $\begin{array}{l}0.014 \\
(1.39)\end{array}$ \\
\hline Great Depression & $\begin{array}{l}-0.033^{* *} \\
(3.93)\end{array}$ & $\begin{array}{l}-0.005 \\
(1.12)\end{array}$ & $\begin{array}{l}-0.003^{* *} \\
(2.86)\end{array}$ & $\begin{array}{l}-0.011^{* *} \\
(2.97)\end{array}$ & $\begin{array}{l}-0.004 \\
(0.98)\end{array}$ & $\begin{array}{l}-0.0005 \\
(0.02)\end{array}$ \\
\hline Tax Amnesty & $\begin{array}{l}0.018 \\
(1.60)\end{array}$ & $\begin{array}{l}0.019 \\
(0.99)\end{array}$ & $\begin{array}{l}0.011 \\
(0.87)\end{array}$ & $\begin{array}{l}0.008 \\
(1.42)\end{array}$ & $\begin{array}{l}0.002 \\
(0.52)\end{array}$ & $\begin{array}{l}0.003 \\
(0.71)\end{array}$ \\
\hline Existence SNB & $\begin{array}{l}-0.018^{*} \\
(2.48)\end{array}$ & $\begin{array}{l}0.0003 \\
(0.12)\end{array}$ & $\begin{array}{l}-0.001 \\
(0.71)\end{array}$ & $\begin{array}{l}-0.021^{* *} \\
(3.82)\end{array}$ & $\begin{array}{l}-0.011^{*} \\
(2.27)\end{array}$ & $\begin{array}{l}-0.006 \\
(1.13)\end{array}$ \\
\hline Devaluation & $\begin{array}{l}-0.012^{*} \\
(2.15)\end{array}$ & $\begin{array}{l}-0.006(*) \\
(1.90)\end{array}$ & $\begin{array}{l}0.0002 \\
(0.04)\end{array}$ & $\begin{array}{l}-0.006 \\
(1.64)\end{array}$ & $\begin{array}{l}-0.006 \\
(1.51)\end{array}$ & $\begin{array}{l}-0.002 \\
(0.64)\end{array}$ \\
\hline $\begin{array}{l}\text { State Old Age Pen- } \\
\text { sion System(AHV) }\end{array}$ & $\begin{array}{l}-0.036 * * \\
(3.24)\end{array}$ & $\begin{array}{l}0.008 \\
(1.64)\end{array}$ & $\begin{array}{l}-0.003 \\
(1.13)\end{array}$ & $\begin{array}{l}-0.010\left(^{*}\right) \\
(1.71)\end{array}$ & $\begin{array}{l}-0.003 \\
(0.48)\end{array}$ & $\begin{array}{l}-0.008 \\
(1.33)\end{array}$ \\
\hline $\begin{array}{l}\text { Proportional } \\
\text { Representation }\end{array}$ & $\begin{array}{l}0.040 * * \\
(2.94)\end{array}$ & $\begin{array}{l}0.018^{* *} \\
(3.30)\end{array}$ & $\begin{array}{l}0.007 \\
(1.38)\end{array}$ & $\begin{array}{l}0.033^{* *} \\
(3.72)\end{array}$ & $\begin{array}{l}0.019\left(^{*}\right) \\
(1.92)\end{array}$ & $\begin{array}{l}0.005 \\
(0.36)\end{array}$ \\
\hline $\begin{array}{l}\text { Time Horizon of } \\
\text { Finance Minister t-1 }\end{array}$ & $\begin{array}{l}-0.001^{* *} \\
(2.95)\end{array}$ & $\begin{array}{l}-0.001^{*} \\
(2.52)\end{array}$ & $\begin{array}{l}-0.003(*) \\
(1.85)\end{array}$ & $\begin{array}{l}-0.001^{*} \\
(2.22)\end{array}$ & $\begin{array}{l}-0.0003 \\
(1.37)\end{array}$ & $\begin{array}{l}0.000 \\
(0.09)\end{array}$ \\
\hline $\begin{array}{l}\text { Number of Referenda } \\
\text { and Initiatives t-1 }\end{array}$ & $\begin{array}{l}0.001 \\
(1.09)\end{array}$ & $\begin{array}{l}0.001 \\
(1.00)\end{array}$ & $\begin{array}{l}0.0001 \\
(0.39)\end{array}$ & $\begin{array}{l}0.001^{*} \\
(2.26)\end{array}$ & $\begin{array}{l}0.001 * \\
(2.38)\end{array}$ & $\begin{array}{l}0.001^{*} \\
(2.32)\end{array}$ \\
\hline Turnout t-1 & $\begin{array}{l}-0.0001 \\
(0.81)\end{array}$ & $\begin{array}{l}-0.0002 \\
(0.61)\end{array}$ & $\begin{array}{l}-0.000 \\
(0.86)\end{array}$ & $\begin{array}{l}-0.0003 \\
(0.87)\end{array}$ & $\begin{array}{l}-0.000 \\
(0.36)\end{array}$ & $\begin{array}{l}-0.000 \\
(1.19)\end{array}$ \\
\hline $\begin{array}{l}\text { Social Democratic } \\
\text { Finance Minister t-1 }\end{array}$ & $\begin{array}{l}0.004 \\
(0.90)\end{array}$ & $\begin{array}{l}-0.009 * * \\
(2.76)\end{array}$ & $\begin{array}{l}-0.012 \\
(1.55)\end{array}$ & $\begin{array}{l}0.003 \\
(1.10)\end{array}$ & $\begin{array}{l}0.001 \\
(0.34)\end{array}$ & $\begin{array}{l}-0.003 \\
(0.62)\end{array}$ \\
\hline $\begin{array}{l}\text { Number of Seats of } \\
\text { Social Democrats in } \\
\text { Parliament t-1 }\end{array}$ & $\begin{array}{l}-0.129 * \\
(2.00)\end{array}$ & $\begin{array}{l}-0.088^{* *} \\
(3.18)\end{array}$ & $\begin{array}{l}-0.107 \\
(1.57)\end{array}$ & $\begin{array}{l}-0.063 \\
(1.55)\end{array}$ & $\begin{array}{l}-0.035 \\
(0.96)\end{array}$ & $\begin{array}{l}-0.018 \\
(0.36)\end{array}$ \\
\hline $\begin{array}{l}\text { Expenditure in \% of } \\
\text { GDP t-1 }\end{array}$ & - & $\begin{array}{l}0.788^{* *} \\
(11.40)\end{array}$ & - & - & - & - \\
\hline $\begin{array}{l}\text { Revenue in \% of } \\
\text { GDP t-1 }\end{array}$ & - & - & - & - & $\begin{array}{l}0.486^{* *} \\
(4.12)\end{array}$ & - \\
\hline Interest rates $\mathrm{t}-1$ & $\begin{array}{l}-0.003 \\
(1.64)\end{array}$ & $\begin{array}{l}0.002^{* *} \\
(3.04)\end{array}$ & $\begin{array}{l}0.004^{*} \\
(2.53)\end{array}$ & $\begin{array}{l}-0.003^{* *} \\
(2.69)\end{array}$ & $\begin{array}{l}-0.001 \\
(1.10)\end{array}$ & $\begin{array}{l}-0.001 \\
(0.72)\end{array}$ \\
\hline Federal income tax & $\begin{array}{l}0.022^{*} \\
(2.29)\end{array}$ & $\begin{array}{l}0.0001 \\
(0.03)\end{array}$ & $\begin{array}{l}0.004 \\
(0.83)\end{array}$ & $\begin{array}{l}0.006 \\
(1.22)\end{array}$ & $\begin{array}{l}-0.001 \\
(0.28)\end{array}$ & $\begin{array}{l}0.000 \\
(0.01)\end{array}$ \\
\hline Time Trend & $\begin{array}{l}0.001^{* *} \\
(3.61)\end{array}$ & $\begin{array}{l}0.001^{* *} \\
(3.08)\end{array}$ & $\begin{array}{l}0.0018(*) \\
(1.93)\end{array}$ & $\begin{array}{l}0.001^{* *} \\
(5.10)\end{array}$ & $\begin{array}{l}0.0004^{*} \\
(2.44)\end{array}$ & $\begin{array}{l}0.0008^{*} \\
(2.39)\end{array}$ \\
\hline Constant & $\begin{array}{l}-1.955^{* *} \\
(3.69)\end{array}$ & $\begin{array}{l}-1.443^{* *} \\
(3.11)\end{array}$ & $\begin{array}{l}-3.314(*) \\
(1.96)\end{array}$ & $\begin{array}{l}-1.437 * * \\
(5.18)\end{array}$ & $\begin{array}{l}-0.712^{*} \\
(2.51)\end{array}$ & $\begin{array}{l}-1.536^{*} \\
(2.44)\end{array}$ \\
\hline Observations & 158 & 158 & 158 & 158 & 158 & 158 \\
\hline $\mathrm{R}^{2}$ & 0.894 & 0.973 & 0.302 & 0.944 & 0.958 & 0.598 \\
\hline D.W. (transformed) & 0.929 & 1.731 & 1.600 & 1.479 & 2.569 & 2.598 \\
\hline RMSE & 0.014 & 0.007 & 0.008 & 0.009 & 0.008 & 0.008 \\
\hline S.W. for normal data & $3.889 * *$ & $4.932 * *$ & $5.736^{* *}$ & $4.930 * *$ & $5.132 * *$ & $3.273^{* *}$ \\
\hline
\end{tabular}


With respect to federal spending in percent of GDP and federal revenue in percent of GDP, the existence of a cointegration relation allows us to estimate error correction models for the whole time period and the two sub-periods also investigating long-run and short-run effects of different variables. In comparison to that, we display also the results for spending and revenue levels since trend stationarity cannot be fully rejected.

The results for the federal budget surplus in percent of GDP are presented in Table 4. The first column shows the results of our regression model with robust standard errors using the $\mathrm{Hu}-$ ber-White sandwich correction and the second column the same model with a Newey-West correction of the standard errors. The Durbin Watson test statistics for the first regression indicates the existence of autocorrelation of the residuals. The reaction of the standard errors to the Newey-West correction does so likewise. In the third column, the model including a lagged endogenous variable is presented, while the $\mathrm{AR}(1)$ regression is shown in the fourth column. In the fifth and sixth columns we exclude the time period of wars and additionally of the recession period during the 1990s (1990-1997) from the sample to control for outliers (see the Shapiro-Wilk-Test for normal data). Overall, across these specifications, the structure of the estimation results remains relatively robust. Given the strong autocorrelation of the residuals, the much stronger variation in significances does not surprise.

Focusing on the regression with a lagged endogenous variable in column 3, it becomes obvious that the federal budget surplus ratio is mainly determined by particular shocks, but also by political factors. The two world wars together with the German-French-War, as expected from the descriptive analysis, strongly and significantly reduce the budget surplus, while the devaluation of the Swiss franc increased the federal surplus. Both variables are significant on the 1 percent level. A larger number of seats in parliament for the social democrats significantly increase the federal budget surplus (at the 1 percent level), though this might be the luck of social democratic finance ministers being in office directly after the Second World War. Party affiliation seems to play a role in the federal council, too, even though there is not much variation in the data. As expected, a longer time horizon of the finance minister has also a positive sign and is significant at the 5 percent level for the whole time period. Regarding the two sub-periods, these results largely remain robust. While the time horizon of the finance minister keeps its significantly positive sign after excluding observations for the periods of the German-French-War, the First World War and the Second World War, it falls to the 90 percent significance level when also excluding the recession period of the 1990s. Anyhow, there is quite a robust relationship between the time horizon of a minister of finance and the 
soundness of public finances giving support to our argument in limiting the incentive to exploit the fiscal commons and in limiting the access to the fiscal commons for lobbies if the minister of finance remains in office for a long time-horizon.

Many of the other control variables, also the economic variables, do not have a robust significant effect on federal budget surpluses in percent of GDP with the important exception of interest rates. A higher number of referenda and initiatives have a weakly significant negative effect on the budget surplus which could be the outcome of the asymmetric restriction direct democracy puts on the revenue side as compared to the spending side on the federal level.

The results for the level of the public debt ratio, presented in the first three columns in Table 5 , contain some similarities to the surplus regressions, but also offer some interesting differences. Again the wars have a significant positive impact on debt. The devaluation in 1936 significantly increased the debt to GDP ratio for the whole period and the two sub-periods. The same holds true for the level of interest rates. Also the number of seats of social democrats in parliament significantly reduces federal debt even though the effect vanishes if we exclude the war periods as well as the recession period. The same is true for social democratic finance ministers. For the whole time period, the switch to proportional representation has a significant positive effect on the level of debt to GDP which does however not hold for the sub-samples. Interestingly, the introduction of a federal income tax is positively associated with increases in the level of the federal debt ratio if we exclude the war-periods. The effect is significant at the 5 percent level and is also remarkable because the level of debt to GDP is stationary for that period. Thus, these estimations for the level of federal debt are particularly reliable.

A closer look at the first differences of the federal debt to GDP ratio reveals largely similar results to the level estimations. ${ }^{8}$ The wars, the devaluation of the Swiss franc and the level of interest rates significantly increase changes in debt to GDP. The only remarkable deviation between the regressions for the level and the change of debt is that the state old pension system proves to be significant for the first differences of federal debt to GDP without the war periods as well as the recession period in the 1990s.

Table 6 presents the results for the error correction model of federal expenditure and revenue to GDP. The first three columns contain the results for the first differences in spending for the full sample and the two sub-periods, while columns (4) to (6) exhibit the respective results for the first differences of federal revenue. Given the cointegration relation between federal spen- 
ding and revenue, it is most interesting that a significant short-run and long-run impact of revenue on expenditure is reported for the full sample, which is not matched by a similar effect of spending on revenue. That the revenue effects on spending vanish for the two sub-periods may be due to the much shorter time period. For the whole sample, these results provide support for the arguments by Peacock and Wiseman (1961) that the ability of a government to raise revenue is a precondition for an extension of public expenditure. In addition, the wars positively and significantly affect spending and revenue. Interest rates prove to be significant and positive in the spending ECM but not for revenue. Otherwise spending appears to be mainly determined by the dynamics between revenue and spending.

In the case of revenue, additional interesting results show up. The oil price and the foundation of the SNB have marginally significant and negative effects on revenue. The introduction of proportional representation significantly increases revenue differences in the whole time period. Similarly, a higher number of referenda and initiatives significantly increase revenue. Both may indicate the ability of the government to raise revenue if the political procedures leading to higher taxation are perceived to be fair by the citizens.

While political stability measured by the time horizon of the finance minister does not significantly affect debt, government spending is significantly lower due to higher political stability also according to the results from the ECM. The same holds regarding the results of the level estimates in Table 7. Looking at the revenue ECM as well as the level estimates, the time horizon of a finance minister plays only a minor role. This is very much in line with the results in the deficit equation. Thus overall, we obtain evidence that political stability induces sound public finances by smaller government spending but only marginally smaller government revenue. The general result supports other empirical evidence of the impact of government stability on the exploitation of the public budget as a fiscal commons.

\section{Conclusion}

In this paper, we have analyzed the impact of political stability on fiscal policy using time series for the Swiss federal level between 1849 and 2007. Theoretically, political stability, interpreted as a factually strong and successful finance minister who stays in office for a long time, may be a possibility to contain the fiscal commons problem of spending ministers exploiting the fiscal resources. Our estimation results are quite heterogeneous across the four budgetary

8. It has to be noted that the first differences in federal debts and the levels in deficits are different since many off-budget activities are included in the federal debt statistics but not in the deficit statistics. 
indicators, i.e. federal surplus, debt, expenditure and revenue, all normalized by GDP. For the federal budget surplus and for federal spending, we obtain evidence that a longer time horizon of the federal finance minister leads to sounder public finances by smaller government spending. However, federal revenue as well as federal debt are largely unaffected by government stability. In the case of government revenue, this is plausible while the results on debt stand in contrast to our predictions.

Fiscal policy in Switzerland appears to be mainly driven by fiscal shocks such as the wars, but also by other events, like the devaluation of the Swiss franc by $30 \%$ in 1936. Of much importance are the dynamics between spending and revenue which provide support for the contention of Peacock and Wiseman (1961) that public spending increase if tax resistance wanes. Finally, some ideological effects can be found though not in the usually assumed direction. If social democrats have more seats in parliament this reduces deficits and debt. Although this might be the luck of a social democratic finance minister being in office during the consolidation after the Second World War, it still adds to the doubts regarding ideological effects.

\section{References}

Afonso, A. and C. Rault (2008), What Do We Really Know About Fiscal Sustainability in the EU? A Panel Data Diagnostic, CESifo Working Paper No. 2226, February 2008.

Alesina, A. and H. Rosenthal (1996), A Theory of Divided Government, Econometrica 64, 1311-1341.

Alt, J.E. and R.C. Lowry (1994), Divided Government, Fiscal Institutions, and Budget Deficits: Evidence from the States, American Political Science Review 88, 811-828.

Altermatt, U. (1991), Die Schweizer Bundesräte, Artemis and Winkler, Zürich.

Baumol, W.J. (1967), Macroeconomics of Unbalanced Growth: The Anatomy of Urban Crisis, American Economic Review 57, 415-426.

Besley, T., and A. Case (1995), Does Electoral Accountability Affect Economic Policy Choices? Evidence from Gubernatorial Term Limits, Quarterly Journal of Economics 110, 769-798.

Besley, T. and A. Case (2003), Political Institutions and Policy Choices: Evidence from United States, Journal of Economic Literature 41, 7-73.

Blais, A., D. Blake and S. Dion (1993), Do Parties Make a Difference? Parties and the Size of Government in Liberal Democracies, American Journal of Political Science 37, 40-62.

Borge, L.-E. (2005), Strong Politicians, Small Deficits: Evidence from Norwegian Local Governments, European Journal of Political Economy 21, 325-344.

Brecht, A. (1932), Internationaler Vergleich der öffentlichen Ausgaben, Grundfragen der internationalen Politik, H. 2, Leipzig and Berlin.

Brennan, G. and J.M. Buchanan (1980), The Power to Tax: Analytical Foundations of a Fiscal Constitution, Cambridge, Cambridge University Press. 
Buchanan, J.M. and G. Tullock (1962), The Calculus of Consent, University of Michigan Press, Ann Arbor.

Buchanan, J.M. and Y.J. Yoon (2004), Majoritarian Exploitation of the Fiscal Commons: General Taxes - Differential Transfers, European Journal of Political Economy 20, 73-90.

Burg, W. von (1916), Die Entwicklung der schweizerischen Bundesfinanzen 1848-1912, Tanner, Bern.

De Haan, J. and J.-E. Sturm (1994), Political Institutions and Institutional Determinants of Fiscal policy in the European Community, Public Choice 80, 157-172.

Feld, L.P. and G. Kirchgässner (2001a), The Political Economy of Direct Legislation: Is There a Role of Direct Democracy in EU Decision-Making?, Economic Policy 33, 329-367.

Feld, L.P. and G. Kirchgässner (2001b), Does Direct Democracy Reduce Public Debt? Evidence from Swiss Municipalities, Public Choice 109, 347-370.

Feld, L.P. and G. Kirchgässner (2008), On the Effectiveness of Debt Brakes: The Swiss Experience, in: R. Neck and J.-E. Sturm (eds.), Sustainability of Public Debt, MIT Press, Cambridge/ London, 223-255.

Feld, L.P. and J.G. Matsusaka (2003), Budget Referendums and Government Spending: Evidence from Swiss Cantons, Journal of Public Economics 87, 2703-2724.

Feld, L.P., C.A. Schaltegger and J. Schnellenbach (2007), On Government Centralization and Fiscal Referendums, European Economic Review 52, 611-645.

Frey, R.L. (2007), Finanzpolitik des Bundes seit 1960, Bericht im Auftrag der Kommission für Konjunkturfragen, Bern.

Funk, P. and C. Gathmann (2007), Does Direct Democracy Reduce the Size of Government? Evidence from Historical Data, 1890 - 2000, Working Paper, Available at SSRN: http://ssrn.com/abstract=1091981.

Gilligan, T. and J.G. Matsusaka (1995), Deviations from Constituent Interest: The Role of Legislative Structure and Political Parties in the States, Economic Inquiry 33, 383-401.

Gilligan, T. and J.G. Matsusaka (2001), Fiscal Policy, Legislature Size, and Political Parties: Evidence from State and Local Governments in the First Half of the 20th Century, National Tax Journal 35, 57-82.

Gruner, E. (1978): Die Wahlen in den Schweizerischen Nationalrat 1848-1919, Francke Bern.

Hagen, J. von (1992), Budgetary Procedures and Fiscal Performance in the European Communities, Commission of the European Communities, Economic Papers No. 96, October.

Hagen, J. von and I.J. Harden (1995), Budget Processes and Commitment to Fiscal Discipline, European Economic Review 39, 771-779.

Hauser, H. Meier, A., H. Müller-Bodmer and M. Rössler (1975), Die Bevölkerungs- und Wirtschaftsstruktur als Bestimmungsfaktor der öffentlichen Ausgaben - Querschnittsanalyse der Ausgaben der Schweizerischen Kantone und Gemeinden, Schweizerische Zeitschrift für Volkswirtschaft und Statistik 111, 93-120.

Hallerberg, M. and J. von Hagen (1999), Electoral Institutions, Cabinet Negotiations, and Budget Deficits in the European Union, in J. Poterba and J. von Hagen (eds.), Fiscal Institutions and Fiscal Performance, Chicago University Press, Chicago, 209-232.

Hallerberg, M., R. Strauch and J. von Hagen (2007), The Design of Fiscal Rules and Forms of Governance in European Union Countries, European Journal of Political Economy 23, 338359.

Hibbs, D.A. (1977), Political Parties and Macroeconomic Policy, American Political Science Review $71,1467-1487$. 
Inman, R.P. and M.A. Fitts (1990), Political Institutions and Fiscal Policy: Evidence from the U.S. Historical Record, Journal of Law, Economics, and Organization 6, 79-132.

Kirchgässner, G. (2002), The Effects of Fiscal Institutions on Public Finance: A Survey of the Empirical Evidence, in: S.L. Winer and H. Shibata (eds.), Political Economy and Public Finance: The Role of Political Economy in the Theory and Practice of Public Economics, Edward Elgar, Cheltenham, 145-177.

Kirchgässner, G. and W.W. Pommerehne (1988), Government Spending in Federal Systems: A Comparison between Germany and Switzerland, in: J. Lybeck and M. Henrekson (eds.), Explaining the Growth of Government, North-Holland, Amsterdam, 327-356.

Kirchgässner, G. and W.W. Pommerehne (1997), Public Spending in Federal States: A Comparative Econometric Study, in: P. Capros und D. Meulders (eds), Modelling Budgetary Policy: Public Spending, Routledge, London, 179-213.

Kirchgässner, G. and S. Prohl (2008), Sustainability of Swiss Fiscal Policy, Swiss Journal of Economics and Statistics 144, 57-83.

Kirchgässner, G. and J. Wolters (2007), Introduction to Modern Time Series Analysis, Springer, Heidelberg et al.

Kontopoulos, Y. and R. Perotti (1999), Government Fragmentation and Fiscal Policy Outcomes: Evidence from OECD Countries, in: J.M. Poterba and J. von Hagen (eds.), Fiscal Institutions and Fiscal Performance, Chicago University Press, Chicago, 81-102.

Lott, J.R., Jr. and L. Kenny (1999), Did Women's Suffrage Change the Size and Scope of Government?, Journal of Political Economy 107, 1163-1198.

Matsusaka, J.G. (1995), Fiscal Effects of the Voter Initiative: Evidence from the Last 30 Years, Journal of Political Economy 103, 587-623.

Matsusaka, J.G. (2004), For the Many of the Few: The Initiative, Public Policy, and American Democracy, Chicago, University of Chicago Press.

Meier, A., H. Hauser, H. Müller-Bodmer and M. Rössler (1973), Die finanziellen Beziehungen in einem föderalistischen System, Wirtschaft und Gesellschaft 9, Mohr Siebeck, Tübingen.

Meltzer, A. and S. Richard (1981), A Rational Theory of the Size of Government, Journal of Political Economy 89, 914-927.

Milesi-Ferretti, G., R. Perotti and M. Rostagno (2002), Electoral Systems and Public Spending, Quarterly Journal of Economics 117, 609-657.

Peacock, A.T. and J. Wiseman (1961), The Growth of Public Expenditures in the United Kingdom, Princeton University Press, Princeton.

Perotti, R. and Y. Kontopoulos (2002), Fragmented Fiscal Policy, Journal of Public Economics 86, 191-222.

Persson, T. and G. Tabellini (2000), Political Economics: Explaining Economic Policy, MIT Press, Cambridge and London.

Persson, T. and G. Tabellini (2003), The Economic Effects of Constitutions: What Do the Data Say?, MIT Press, Cambridge and London.

Pommerehne, W.W. (1978), Institutional Approaches to Public Expenditure: Empirical Evidence from Swiss Municipalities, Journal of Public Economics 9, 255-280.

Pommerehne, W.W. and B.S. Frey (1976), Two Approaches to Estimating Public Expenditures, Public Finance Quarterly 4, 395-407.

Pommerehne, W.W. and F. Schneider (1978), Fiscal Illusion, Political Institutions, and Local Public Spending, Kyklos 31, 381-408. 
Popitz, J. (1927): Der Finanzausgleich, in: W. Gerloff und F. Meisel (eds.), Handbuch der Finanzwissenschaft, Bd. 2, Tübingen, 338-375.

Poterba, J.M. (1997), Do Budget Rules Work?, in: A.J. Auerbach (ed.), Fiscal Policy: Lessons from Economic Research, MIT Press, Cambridge (Mass.) 1997, 53-86.

Roubini, N. and J. Sachs (1989a), Political and Economic Determinants of Budget Deficits in the Industrial Economies, European Economic Review 33, 903-938.

Roubini, N and J. Sachs (1989b), Government Spending and Budget Deficits in the Industrialized Countries, Economic Policy 8, 99-132.

Samuelson, P.A. (1954), Pure Theory of Public Expenditure, Review of Economics and Statistics 40, 332-338.

Schaltegger, C.A. (2002), Budgetregeln und ihre Wirkung auf die öffentlichen Haushalte: Empirische Ergebnisse aus den US-Bundesstaaten und den Schweizer Kantonen, Schmollers Jahrbuch 122, 369-413.

Schaltegger, C.A. and L.P. Feld (2009), Do Large Cabinets Favor Large Governments?, Evidence on the Fiscal Commons Problem for Swiss Cantons, Journal of Public Economics 93, 35-47.

Schumpeter, J.A. (1918, [1953]), Die Krise des Steuerstaates, Zeitfragen aus dem Gebiet der Soziologie 4, reprinted in: J.A. Schumpeter (1953), Aufsätze zur Soziologie, Mohr Siebeck, Tübingen.

Tridimas, G. and S. Winer (2005), The Political Economy of Government Size, European Journal of Political Economy 21, 643-666.

Velasco, A. (1999), A Model of Endogenous Fiscal Deficits and Delayed Fiscal Reforms, in: J. Poterba and J. v. Hagen (eds.), Fiscal Institutions and Fiscal Performance, Chicago University Press and NBER, Chicago, 37-57.

Velasco, A. (2000), Debts and Deficits with Fragmented Fiscal Policymaking, Journal of Public Economics 76, 105-125.

Volkerink, B. and J. de Haan (2001), Fragmented Government Effects on Fiscal Policy: New Evidence, Public Choice 109, 221-242.

Wagner, A. (1892), Grundlegung der politischen Ökonomie, C. F. Winter'sche Verlagshandlung, Leipzig.

Wallis, J.J. (1991), The Political Economy of New Deal Fiscal Federalism, Economic Inquiry 29, 510524.

Wallis, J.J. (2000), American Government Finance in the Long Run: 1790 to 1990, Journal of Economic Perspectives 14 (1), 61-82.

Weber, M. (1969), Geschichte der schweizerischen Bundesfinanzen, Bern, Paul Haupt.

Weingast, B.R., K.Shepsle and C. Johnson (1981), The Political Economy of Benefits and Costs: A Neoclassical Approach to Distributive Politics, Journal of Political Economy 96, 132-163. 


\section{Appendix A}

\begin{tabular}{|c|c|c|}
\hline \multicolumn{3}{|c|}{ Table A: Data description } \\
\hline Variable name & Description & Source \\
\hline Expenditure & Federal expenditure divided by GDP & $\begin{array}{l}\text { 1950-2007: Swiss Federal Finance } \\
\text { Administration, Swiss Federal Statistical } \\
\text { Office } \\
\text { 1913-1949: Swiss Federal Department of } \\
\text { Finance, Swiss Federal Statistical Office } \\
\text { 1849-1912: Walter von Burg (1916) }\end{array}$ \\
\hline Revenue & Federal revenue divided by GDP & $\begin{array}{l}\text { 1950-2007: Swiss Federal Finance } \\
\text { Administration, Swiss Federal Statistical } \\
\text { Office } \\
\text { 1913-1949: Swiss Federal Department of } \\
\text { Finance, Swiss Federal Statistical Office } \\
\text { 1849-1912: Walter von Burg (1916) }\end{array}$ \\
\hline Surplus & Federal budget surplus divided by GDP & $\begin{array}{l}\text { 1950-2007: Swiss Federal Finance } \\
\text { Administration, Swiss Federal Statistical } \\
\text { Office } \\
\text { 1913-1949: Swiss Federal Department of } \\
\text { Finance, Swiss Federal Statistical Office } \\
\text { 1849-1912: Walter von Burg (1916) }\end{array}$ \\
\hline Debts & Federal debts divided by GDP & $\begin{array}{l}\text { 1950-2007: Swiss Federal Finance } \\
\text { Administration, Swiss Federal Statistical } \\
\text { Office } \\
\text { 1913-1949: Swiss Federal Department of } \\
\text { Finance, Swiss Federal Statistical Office } \\
\text { 1849-1912: Walter von Burg (1916) }\end{array}$ \\
\hline Oil Price & $\begin{array}{l}\text { Crude oil price in US Dollars per barrel } \\
\text { (in } 2006 \text { \$) }\end{array}$ & $\begin{array}{l}\text { BP Statistical Review of World Energy, } \\
\text { June } 2007\end{array}$ \\
\hline GDP & Real GDP, $1990=100$ & $\begin{array}{l}\text { 1851-1913: Historische Statistik der } \\
\text { Schweiz, Cronos (1996) } \\
\text { 1914-1947: Andrist/ Anderson/ Williams: } \\
\text { Real Output in Switzerland in Quarterly } \\
\text { Review Federal Reserve Bank St.Louis, } \\
\text { USA } \\
\text { 1948-2007: Bundesamt für Statistik, } \\
\text { Volkswirtschaftliche Gesamtrechnungen } \\
\text { (BFS) }\end{array}$ \\
\hline Population & Total Regular Population & Swiss Federal Statistical Office \\
\hline Wars & $\begin{array}{l}\text { Dummy=1 for years with German-French } \\
\text { War, World War I and World War II }\end{array}$ & Own calculations \\
\hline Great Depression & $\begin{array}{l}\text { Dummy=1 for years between } 1929 \text { and } \\
1933\end{array}$ & Own calculations \\
\hline Tax Amnesty & $\begin{array}{l}\text { Dummy=1 for year with tax amnesty on } \\
\text { the federal level }(1940,1945,1969)\end{array}$ & $\begin{array}{l}\text { Documentation of the Swiss Federal Tax } \\
\text { Administration }\end{array}$ \\
\hline Existence SNB & $\begin{array}{l}\text { Dummy }=1 \text { for years after the founding of } \\
\text { the Swiss central bank SNB in } 1907\end{array}$ & $\begin{array}{l}\text { Die Schweizerische Nationalbank 1907- } \\
\text { 2007, NZZ, Zürich }\end{array}$ \\
\hline Devaluation & $\begin{array}{l}\text { Dummy=1 for year of the } 30 \%- \\
\text { devaluation of the Swiss currency in } 1936\end{array}$ & $\begin{array}{l}\text { Die Schweizerische Nationalbank 1907- } \\
\text { 2007, NZZ, Zürich }\end{array}$ \\
\hline $\begin{array}{l}\text { State Old Pension } \\
\text { System (AHV) }\end{array}$ & $\begin{array}{l}\text { Dummy }=1 \text { for year after introduction of } \\
\text { the Old Pension System AHV in } 1948\end{array}$ & Own calculations \\
\hline
\end{tabular}




\begin{tabular}{|c|c|c|}
\hline $\begin{array}{l}\text { Proportional } \\
\text { Representation }\end{array}$ & $\begin{array}{l}\text { Dummy=1 for years after introduction of } \\
\text { proportional electoral system in } 1919 .\end{array}$ & Swiss Chancellerie \\
\hline $\begin{array}{l}\text { Time Horizon of } \\
\text { Finance Minister }\end{array}$ & $\begin{array}{l}\text { Number of years until the end of the term } \\
\text { for the respective minister of finance }\end{array}$ & $\begin{array}{l}\text { Urs Altermatt (1991), Die Schweizer } \\
\text { Bundesräte, Artemis and Winkler, Zürich }\end{array}$ \\
\hline Number of Referenda & $\begin{array}{l}\text { Number of voter initiatives and public } \\
\text { referenda in a year on the federal level }\end{array}$ & Swiss Chancellerie \\
\hline Turnout & $\begin{array}{l}\text { Average voter turnout of the voter } \\
\text { initiatives and public referenda in a year } \\
\text { on the federal level with } 0=\text { no } \\
\text { referendum or initiative was held }\end{array}$ & Swiss Chancellerie \\
\hline $\begin{array}{l}\text { Social democratic } \\
\text { minister of finance }\end{array}$ & $\begin{array}{l}\text { Dummy=1 if the finance minister belongs } \\
\text { to the social democratic party }\end{array}$ & Swiss Chancellerie \\
\hline Social Democrats & $\begin{array}{l}\text { Share of seats in the house of } \\
\text { representatives held by members of the } \\
\text { social democratic party }\end{array}$ & $\begin{array}{l}\text { 1849-1918: Erich Gruner (1978): Die } \\
\text { Wahlen in den Schweizerischen Nationalrat } \\
\text { 1848-1919, Francke Bern } \\
\text { 1919-2007: Swiss Federal Statistical Office }\end{array}$ \\
\hline Time trend & Time variable from 1849-2007 & Own calculations \\
\hline Interest Rates & Bond yields, nominal, average of the year & $\begin{array}{l}\text { 1849 - 1898: Interest rates on savings } \\
\text { deposits in Switzerland, regional average } \\
\text { 1899-2007: Yields on Swiss Confederation } \\
\text { bonds }\end{array}$ \\
\hline DBST & $\begin{array}{l}\text { Dummy=1 for year with a federal income } \\
\text { tax in } 1916,1917,1921,1924,1925, \\
1928,1929,1932,1940-2007\end{array}$ & $\begin{array}{l}\text { Documentation of the Swiss Federal Tax } \\
\text { Administration }\end{array}$ \\
\hline
\end{tabular}




\section{Appendix B}

\section{Table B: Descriptive statistics}

\begin{tabular}{|lllll|}
\hline Variable & Mean & Std. Dev. & Minimum & Maximum \\
\hline Budget surplus divided by GDP & -0.005 & 0.019 & -0.130 & 0.021 \\
Debt divided by GDP & 0.146 & 0.137 & 0.001 & 0.632 \\
Revenue divided by GDP & 0.060 & 0.034 & 0.016 & 0.142 \\
Expenditure divided by GDP & 0.063 & 0.041 & 0.010 & 0.186 \\
Time trend & 1928 & 46.044 & 1849 & 2007 \\
Wars & 0.088 & 0.284 & 0 & 1 \\
Proportional representation & 0.553 & 0.499 & 0 & 1 \\
Devaluation & 0.006 & 0.079 & 0 & 1 \\
Existence SNB & 0.635 & 0.4829 & 0 & 1 \\
Great depression & 0.031 & 0.175 & 0 & 1 \\
Time horizon of finance minister & 4.344 & 3.247 & 1 & 14 \\
Social-democratic minister & 0.164 & 0.371 & 0 & 1 \\
Old age pension system & 0.3774 & 0.486 & 0 & 1 \\
Oil price & 25.210 & 18.515 & 8.665 & 104.354 \\
Population & 4435557 & 153308 & 2392740 & 7508739 \\
GDP & 77.206 & 131.749 & 0.659 & 504.167 \\
Tax amnesty & 0.019 & 0.136 & 0 & 1 \\
DBST & 0.478 & 0.501 & 0 & 1 \\
Nominal interest rates & 4.047 & 0.865 & 2.106 & 7.118 \\
Voter turn-out & 38.928 & 238427 & 0 & 80.509 \\
Ballots & 1.862 & 1.536 & 0 & 9 \\
Share of social democrats & 0.174 & 0.092 & 0 & 0.2887 \\
\hline Note: & & & & \\
For a detailed description of the variables see Appendix & A. & \\
All statistics are computed for 159 observations. & & \\
\hline
\end{tabular}




\section{Appendix C}

\begin{tabular}{|c|c|c|c|}
\hline Term & Name & Party affiliation & citizenship \\
\hline $1848 / 50$ & Martin Josef Munzinger & FDP & SO \\
\hline 1851 & Henry Druey & FDP & VD \\
\hline 1852 & Martin Josef Munzinger & FDP & SO \\
\hline $1853 / 54$ & Henry Druey & FDP & $\mathrm{VD}$ \\
\hline $1855 / 56$ & Melchior Josef Martin Knüsel & FDP & LU \\
\hline $1857 / 58$ & Jakob Stämpfli & FDP & $\mathrm{BE}$ \\
\hline 1859/61 & Constant Fornerod & FDP & VD \\
\hline $1862 / 63$ & Melchior Josef Martin Knüsel & FDP & LU \\
\hline $1864 / 67$ & Jacques Callet-Venel & FDP & GE \\
\hline 1868 & Victor Ruffy & FDP & VD \\
\hline 1869 & Jacques Callet-Venel & FDP & GE \\
\hline 1870/71 & Paul Cérésole & FDP & VD \\
\hline 1872 & Karl Schenk & FDP & $\mathrm{BE}$ \\
\hline 1873 & Johann Jakob Scherrer & FDP & $\mathrm{ZH}$ \\
\hline $1874 / 75$ & Wilhelm Mathias Naeff & FDP & SG \\
\hline 1876/78 & Bernhard Hammer & FDP & SO \\
\hline 1879 & Simeon Bavier & FDP & GR \\
\hline 1880/91 & Bernhard Hammer & FDP & SO \\
\hline 1892/99 & Walther Hauser & FDP & $\mathrm{ZH}$ \\
\hline 1900 & Robert Comtesse & FDP & $\mathrm{NE}$ \\
\hline 1901/02 & Walther Hauser & FDP & $\mathrm{ZH}$ \\
\hline 1903 & Robert Comtesse & FDP & $\mathrm{NE}$ \\
\hline 1904 & Marc-Emile Ruchet & FDP & VD \\
\hline 1905/09 & Robert Comtesse & FDP & $\mathrm{NE}$ \\
\hline 1910 & Josef Anton Schobinger & FDP & LU \\
\hline 1911 & Robert Comtesse & FDP & $\mathrm{NE}$ \\
\hline 1912/19 & Giuseppe Motta & CVP & $\mathrm{TI}$ \\
\hline 1920/34 & Jean-Mary Musy & CVP & VD \\
\hline 1935/38 & Albert Meyer & FDP & $\mathrm{ZH}$ \\
\hline $1939 / 43$ & Ernst Wetter & FDP & $\mathrm{ZH}$ \\
\hline 1944/51 & Ernst Nobs & SP & $\mathrm{ZH}$ \\
\hline 1952/54 & Max Weber & SP & $\mathrm{ZH}$ \\
\hline $1954 / 59$ & Hans Streuli & FDP & $\mathrm{ZH}$ \\
\hline 1960/62 & Jean Bourgknecht & CVP & FR \\
\hline 1963/68 & Roger Bonvin & CVP & VS \\
\hline 1968/73 & Nello Celio & FDP & $\mathrm{TI}$ \\
\hline $1974 / 79$ & Georges-André Chevallaz & FDP & VD \\
\hline 1980/83 & Willi Ritschard & SP & SO \\
\hline 1984/95 & Otto Stich & SP & SO \\
\hline 1996/03 & Kaspar Villiger & FDP & LU \\
\hline 2004- & Hans-Rudolf Merz & FDP & AR \\
\hline
\end{tabular}




\section{CESifo Working Paper Series}

for full list see www.cesifo-group.org/wp

(address: Poschingerstr. 5, 81679 Munich, Germany, office@cesifo.de)

2629 Håkan Selin, The Rise in Female Employment and the Role of Tax Incentives - An Empirical Analysis of the Swedish Individual Tax Reform of 1971, April 2009

2630 Nick Johnstone and Ivan Hascic, Environmental Policy Design and the Fragmentation of International Markets for Innovation, April 2009

2631 Spiros Bougheas, Richard Kneller and Raymond Riezman, Optimal Education Policies and Comparative Advantage, April 2009

2632 Jay Pil Choi and Heiko Gerlach, Multi-Market Collusion with Demand Linkages and Antitrust Enforcement, April 2009

2633 Thor O. Thoresen, Income Mobility of Owners of Small Businesses when Boundaries between Occupations are Vague, April 2009

2634 Guido Schwerdt and Amelie C. Wuppermann, Is Traditional Teaching really all that Bad? A Within-Student Between-Subject Approach, April 2009

2635 Kurt R. Brekke, Luigi Siciliani and Odd Rune Straume, Hospital Competition and Quality with Regulated Prices, April 2009

2636 Peter Diamond, Taxes and Pensions, April 2009

2637 Shoshana Grossbard, How "Chicagoan" are Gary Becker's Economic Models of Marriage?, May 2009

2638 Roland Strausz, Regulatory Risk under Optimal Incentive Regulation, May 2009

2639 Holger Zemanek, Ansgar Belke and Gunther Schnabl, Current Account Imbalances and Structural Adjustment in the Euro Area: How to Rebalance Competitiveness, May 2009

2640 Harald Hau and Marcel Thum, Subprime Crisis and Board (In-)Competence: Private vs. Public Banks in Germany, May 2009

2641 Martin Halla, Mario Lackner and Friedrich G. Schneider, An Empirical Analysis of the Dynamics of the Welfare State: The Case of Benefit Morale, May 2009

2642 Balázs Égert, Infrastructure Investment in Network Industries: The Role of Incentive Regulation and Regulatory Independence, May 2009

2643 Christian Gollier, Expected Net Present Value, Expected Net Future Value, and the Ramsey Rule, May 2009

2644 Sören Blomquist and Håkan Selin, Hourly Wage Rate and Taxable Labor Income Responsiveness to Changes in Marginal Tax Rates, May 2009 
2645 Dominique Demougin, Oliver Fabel and Christian Thomann, Implicit vs. Explicit Incentives: Theory and a Case Study, May 2009

2646 Francesco C. Billari and Vincenzo Galasso, What Explains Fertility? Evidence from Italian Pension Reforms, May 2009

2647 Kjell Arne Brekke, Karen Evelyn Hauge, Jo Thori Lind and Karine Nyborg, Playing with the Good Guys - A Public Good Game with Endogenous Group Formation, May 2009

2648 Guglielmo Maria Caporale and Luis A. Gil-Alana, Multi-Factor Gegenbauer Processes and European Inflation Rates, May 2009

2649 Henning Bohn, A Static Model for Voting on Social Security, May 2009

2650 Markus Haavio and Kaisa Kotakorpi, The Political Economy of Sin Taxes, May 2009

2651 Augusto de la Torre, María Soledad Martínez Pería and Sergio L. Schmukler, Drivers and Obstacles to Banking SMEs: The Role of Competition and the Institutional Framework, May 2009

2652 Tobias Lindhe and Jan Södersten, Dividend Taxation, Share Repurchases and the Equity Trap, May 2009

2653 Assaf Razin and Edith Sand, Migration-Regime Liberalization and Social Security: Political-Economy Effect, May 2009

2654 Yin-Wong Cheung and Hiro Ito, A Cross-Country Empirical Analysis of International Reserves, May 2009

2655 Bart Cockx and Bruno Van der Linden, Flexicurity in Belgium. A Proposal Based on Economic Principles, May 2009

2656 Michael Melvin, Lukas Menkhoff and Maik Schmeling, Exchange Rate Management in Emerging Markets: Intervention via an Electronic Limit Order Book, May 2009

2657 Susanne Neckermann, Reto Cueni and Bruno S. Frey, What is an Award Worth? An Econometric Assessment of the Impact of Awards on Employee Performance, May 2009

2658 Steven Brakman, Harry Garretsen and Charles van Marrewijk, Economic Geography within and between European Nations: The Role of Market Potential and Density across Space and Time, May 2009

2659 Giovanni Facchini and Cecilia Testa, Reforming Legislatures: Is one House better than two?, May 2009

2660 Carsten Kowalczyk and Raymond Riezman, Trade Agreements, May 2009 
2661 Oliver Falck, Stephan Heblich and Elke Luedemann, Identity and Entrepreneurship, May 2009

2662 Christian Lessmann and Gunther Markwardt, One Size Fits All? Decentralization, Corruption, and the Monitoring of Bureaucrats, May 2009

2663 Felix Bierbrauer, On the Legitimacy of Coercion for the Financing of Public Goods, May 2009

2664 Alessandro Cigno, Agency in Family Policy: A Survey, May 2009

2665 Claudia M. Buch and Christian Pierdzioch, Low Skill but High Volatility?, May 2009

2666 Hendrik Jürges, Kerstin Schneider, Martin Senkbeil and Claus H. Carstensen, Assessment Drives Learning: The Effect of Central Exit Exams on Curricular Knowledge and Mathematical Literacy, June 2009

2667 Eric A. Hanushek and Ludger Woessmann, Schooling, Cognitive Skills, and the Latin American Growth Puzzle, June 2009

2668 Ourania Karakosta, Christos Kotsogiannis and Miguel-Angel Lopez-Garcia, Does Indirect Tax Harmonization Deliver Pareto Improvements in the Presence of Global Public Goods?, June 2009

2669 Aleksandra Riedl and Silvia Rocha-Akis, Testing the Tax Competition Theory: How Elastic are National Tax Bases in OECD Countries?, June 2009

2670 Dominique Demougin and Carsten Helm, Incentive Contracts and Efficient Unemployment Benefits, June 2009

2671 Guglielmo Maria Caporale and Luis A. Gil-Alana, Long Memory in US Real Output per Capita, June 2009

2672 Jim Malley and Ulrich Woitek, Productivity Shocks and Aggregate Cycles in an Estimated Endogenous Growth Model, June 2009

2673 Vivek Ghosal, Business Strategy and Firm Reorganization under Changing Market Conditions, June 2009

2674 Francesco Menoncin and Paolo M. Panteghini, Retrospective Capital Gains Taxation in the Real World, June 2009

2675 Thomas Hemmelgarn and Gaëtan Nicodème, Tax Co-ordination in Europe: Assessing the First Years of the EU-Savings Taxation Directive, June 2009

2676 Oliver Himmler, The Effects of School Competition on Academic Achievement and Grading Standards, June 2009

2677 Rolf Golombek and Michael Hoel, International Cooperation on Climate-Friendly Technologies, June 2009 
2678 Martin Cave and Matthew Corkery, Regulation and Barriers to Trade in Telecommunications Services in the European Union, June 2009

2679 Costas Arkolakis, A Unified Theory of Firm Selection and Growth, June 2009

2680 Michelle R. Garfinkel, Stergios Skaperdas and Constantinos Syropoulos, International Trade and Transnational Insecurity: How Comparative Advantage and Power are Jointly Determined, June 2009

2681 Marcelo Resende, Capital Structure and Regulation in U.S. Local Telephony: An Exploratory Econometric Study; June 2009

2682 Marc Gronwald and Janina Ketterer, Evaluating Emission Trading as a Policy Tool Evidence from Conditional Jump Models, June 2009

2683 Stephan O. Hornig, Horst Rottmann and Rüdiger Wapler, Information Asymmetry, Education Signals and the Case of Ethnic and Native Germans, June 2009

2684 Benoit Dostie and Rajshri Jayaraman, The Effect of Adversity on Process Innovations and Managerial Incentives, June 2009

2685 Peter Egger, Christian Keuschnigg and Hannes Winner, Incorporation and Taxation: Theory and Firm-level Evidence, June 2009

2686 Chrysovalantou Milliou and Emmanuel Petrakis, Timing of Technology Adoption and Product Market Competition, June 2009

2687 Hans Degryse, Frank de Jong and Jérémie Lefebvre, An Empirical Analysis of Legal Insider Trading in the Netherlands, June 2009

2688 Subhasish M. Chowdhury, Dan Kovenock and Roman M. Sheremeta, An Experimental Investigation of Colonel Blotto Games, June 2009

2689 Alexander Chudik, M. Hashem Pesaran and Elisa Tosetti, Weak and Strong Cross Section Dependence and Estimation of Large Panels, June 2009

2690 Mohamed El Hedi Arouri and Christophe Rault, On the Influence of Oil Prices on Stock Markets: Evidence from Panel Analysis in GCC Countries, June 2009

2691 Lars P. Feld and Christoph A. Schaltegger, Political Stability and Fiscal Policy - Time Series Evidence for the Swiss Federal Level since 1849, June 2009 